\title{
PLANO DE PROTEÇÃO DE AQÜÍFEROS A PARTIR DE VARIÁVEIS AMBIENTAIS
}

\section{Aquifers Protection Plan from Environmental Variables}

\author{
Denecir de Almeida DUTRA ${ }^{1}$ \\ Quelen da Silva OSÓRIO² \\ Roberto CASSOL ${ }^{3}$
}

\begin{abstract}
RESUMO
Elaborou-se um plano de proteção para os aqüíferos na área de abrangência da microbacia hidrográfica do Arroio Ferreira, localizada no município de Santa Maria/RS; além de identificar as variáveis sócio-ambientais presentes na mesma e elaborar planos de informação com o uso das técnicas de SIG estabelecendo-se seus cruzamentos. Obtiveram-se assim cinco zonas de proteção dos aqüíferos, denominadas: Zona I - Proteção imediata, Zona II - Restrição e controle, Zona III - Baixa restrição, Zona IV - Prevenção e Zona V - Influência direta de cursos de água, que foram adaptadas das legislações existentes para proteção dos poços e áreas de recarga aqüífera. Observou-se que a microbacia apresenta condições naturais propícias à contaminação das águas subterrâneas, além de fazer parte hidrogeológicamente do Sistema Aqüífero Guarani.
\end{abstract}

Palavras-chave: águas subterrâneas; bacia hidrográfica; gestão ambiental.

\begin{abstract}
The present study proposes a plan of protection of aquifers for the watershed of the Arroio Ferreira, located in the municipality of Santa Maria/RS. Besides identifying to the partner-ambient variables of the watershed one and elaborating plans of information with the use of the SIG techniques establishing itself its crossings. Thus, defined five zones of protection of the aquifers, called: Zone I - Immediate protection, Zone II - Restriction and control, Zone III - Little restriction, Zone IV - Prevention and Zone $V$ - Direct influence from watercourse, adapted of the norms established for the protection of the wells and areas of aquifers recharge, as well as of previous works. As we could observe the watershed of the Arroio Ferreira presents propitious natural conditions for the contamination of groundwater's, besides being part of the Guarani Aquifer System.
\end{abstract}

Keywords: groundwater; watershed; ambient management.

1 Graduado em Geografia, Especialista em Educação Ambiental e Mestre em Geomática pela Universidade Federal de Santa Maria; Doutorando do Programa de Pós-Graduação em Geografia da Universidade Federal do Paraná. E-mail: denecir.dutra@terra.com.br

2 Graduada em Geografia e Mestre em Geomática pela Universidade Federal de Santa Maria; Doutoranda do Programa de PósGraduação em Geologia da Universidade Federal do Paraná.

3 Prof. Dr. do Departamento de Geociências, Centro de Ciências Naturais e Exatas da Universidade Federal de Santa Maria. 


\section{INTRODUÇÃO}

A reserva de água disponível, economicamente viável para o consumo humano, restringe-se aquela parcela que se encontra na forma de água superficial e subterrânea, que representa cerca de $0,7 \%$ da água doce existente na superfície da Terra. As outras formas de ocorrência de água na crosta terrestre são de difícil acesso para o homem, principalmente pelo alto custo de exploração e tratamento, como também pela própria falta de disponibilidade física, no caso da água do solo (HASSUDA, 1999).

Apesar da importância da água subterrânea como insumo básico para o abastecimento público e para indústria, precisa-se de investimentos para aprofundar um nível de conhecimento técnico científico que possibilite avanços na exploração, aproveitamento e proteção desses recursos hídricos. A atividade de captação e exploração das águas subterrâneas dependem de dispositivos institucionais que disciplinem, controlem ou fiscalizem o seu exercício. A falta desses instrumentos legais coloca em risco a qualidade dos aqüíferos que, uma vez poluídos ou contaminados, sua recuperação é de longa duração, tecnicamente difícil e muitas vezes economicamente inviável (COELHO; DUARTE, 2003).

Em função disso, observa-se que a melhor forma de manter a boa qualidade da água subterrânea é sua prevenção. Evidentemente, locais que já se encontram contaminados devem passar por um processo de remediação para recuperação da área e evitar danos à saúde pública e ao meio ambiente. Atualmente, existem instrumentos que visam proteger diretamente, tanto os aqüíferos, como também os poços de abastecimento. A metodologia de delimitação desses perímetros pode basear-se no desenvolvimento analítico das fórmulas que regem o fluxo da água subterrânea até o uso de modelos matemáticos numéricos complexos (HASSUDA, 1999).

Nesse contexto, o objetivo deste trabalho foi propor um plano de proteção dos aqüíferos para a microbacia hidrográfica do Arroio Ferreira, Santa Maria/ RS. Para tanto foi necessário identificar as variáveis sócio-ambientais presentes na área, elaborar planos de informação com o uso das técnicas de geoprocessamento e estabelecer cruzamento para obter-se as zonas de proteção dos aqüíferos.

\section{APRESENTAÇÃO DA ÁREA DE ESTUDO}

A microbacia hidrográfica do Arroio Ferreira está localizada entre as coordenadas Universal Transversa de Mercator - UTM de $6720000 \mathrm{mN}$ e $6708000 \mathrm{mN}$, $216000 \mathrm{mE}$ e $228000 \mathrm{mE}$ (Figura 1). Possui uma superfície de 5.207,72 ha e situa-se na zona Oeste do município de Santa Maria, Região Central do Estado do Rio Grande do Sul, Brasil.

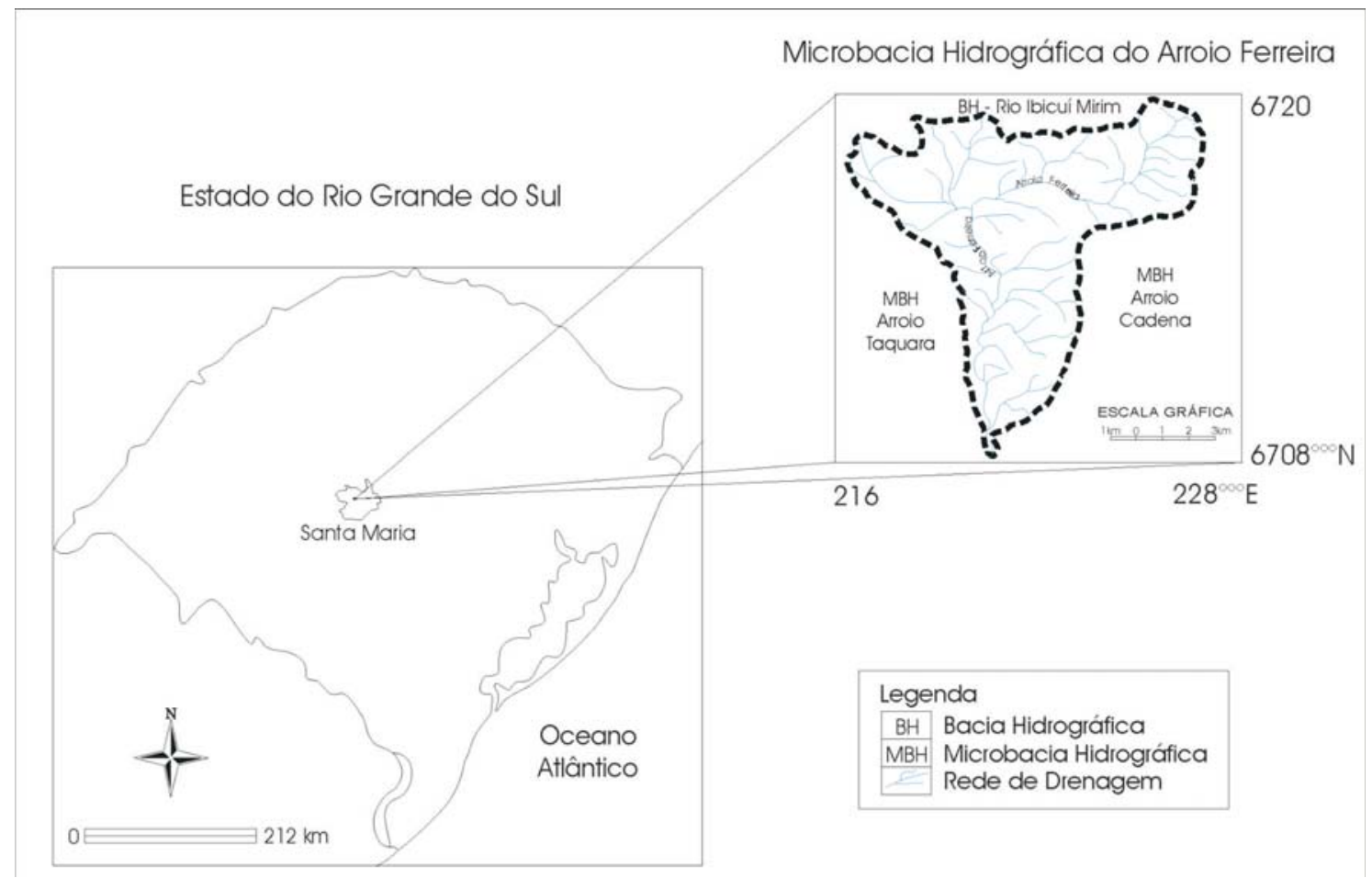

FIGURA 1 - LOCALIZAÇÃO DA MICROBACIA HIDROGRÁFICA DO ARROIO FERREIRA 
Abrange em seus limites o Distrito Industrial de Santa Maria, os bairros Tancredo Neves, parcela dos Bairros Parque Pinheiro Machado, Conjunto Habitacional Santa Marta e Nova Santa Marta, além da Vila Esmeralda e ocupações clandestinas; totalizando uma população de 30 mil pessoas (estimada de acordo com os Setores Censitários do IBGE, 2000). É interceptada por duas rodovias pavimentadas (BR 158 e RST 287), uma ferrovia e diversos caminhos que facilitam o acesso e interligação aos diferentes pontos da microbacia, que se intercala entre a zona industrial, urbana e rural.

A microbacia hidrográfica do Arroio Ferreira possui forma triangular, de acordo com a classificação de Christofoletti (1980), e o padrão de drenagem caracteriza-se por ser dendrítico ou arborescente, onde as ramificações da hidrografia são semelhantes a galhos de árvores, porque ocorrem tipicamente sobre rochas de resistência uniforme e/ou em rochas sedimentares estratificadas.

A área da microbacia limita-se à Oeste com a microbacia do Arroio Taquara, a Leste com a microbacia do Arroio Cadena e ao Norte com a bacia hidrográfica do Rio Ibicuí Mirim. Identificaram-se cinqüenta rios de primeira ordem, onze rios de segunda ordem, dois rios de terceira ordem e um rio de quarta ordem de drenagem. O rio principal (Arroio Ferreira) apresenta uma extensão total de 18.735,78 metros e faz parte da Bacia do Sudeste (MOREIRA, 1995), pois é afluente do Arroio Picadinho que deságuam no Arroio Arenal que desemboca no rio Vacacaí, que por sua vez flui para o rio Jacuí chegando até o Lago Guaíba.

O clima, apesar de quente úmido durante boa parte do ano, conserva por apreciável período o caráter frio, capaz de imprimir restrições à proliferação e ao desenvolvimento de grande número de espécies tipicamente tropicais (MOREIRA, 1995).

Segundo dados da CPRM (1994), a precipitação média anual é de $1.769 \mathrm{~mm}$ e os meses de maio, junho e setembro são mais chuvosos, enquanto novembro e dezembro são mais secos. A média anual da temperatura é de $19,2^{\circ} \mathrm{C}$, com amplitude térmica da ordem de $10^{\circ} \mathrm{C}$. O trimestre mais quente (dezembro, janeiro e fevereiro) apresenta como média $24,2^{\circ} \mathrm{C}$, ao passo que o trimestre mais frio (junho, julho e agosto) a média é de $14,4^{\circ} \mathrm{C}$.

A vegetação caracteriza-se como Floresta Ombrófila Densa, Ombrófila Temperada e Floresta Estacional Decidual, atualmente encontram-se no Rebordo do Planalto as Florestas Subcaducifólia Subtropical, formada por espécies arbóreas, arbustívas e rasteiras. $\mathrm{Na}$ depressão ocorrem os campos mistos com várias espécies de gramíneas. Ao longo dos cursos de água existem várias espécies arbóreas de caráter mais ou menos higrófilo, constituindo as matas galerias (RADAMBRASIL, 1986).

\section{METODOLOGIA}

\section{PROCEDIMENTO METODOLÓGICO}

O referencial teórico-metodológico proposto para determinar o Plano de Proteção dos Aqüíferos na microbacia hidrográfica do Arroio Ferreira, a partir da definição de diferentes zonas de proteção dos aqüíferos, seguiu inicialmente o levantamento de dados cartográficos préexistentes (carta topográfica, mapa geológico e imagem de satélite) que informaram as condições ambientais da área estudada.

Posteriormente, executou-se a integração e tratamento desses dados, convertendo-os para o formato digital por meio do emprego do sistema de informações geográficas e das técnicas de geoprocessamento. As condições de permeabilidade foram obtidas em função da composição litológica das formações aflorantes na microbacia, enquanto a profundidade do nível da água subterrânea foi estimada a partir do nível estático dos poços e emprego do programa Surfer 6.0.

Por fim, executou-se o cruzamento das informações referentes às características do meio físico-natural com a situação de uso e ocupação do solo.

As definições adotadas para as zonas de proteção propostas neste trabalho foram adaptadas das normas estabelecidas para a proteção dos poços (captações de água) e das áreas de recarga aqüífera. Dessa forma, o Plano de Proteção dos Aqüíferos na microbacia hidrográfica do Arroio Ferreira deve obedecer ao zoneamento de proteção proposto e definido a seguir:

Zona I - Proteção imediata: compreende, no todo ou em parte, zonas de aqüífero sedimentar poroso, declividades menores do que $5 \%$ e entre 5 e $12 \%$, energia do relevo menor que 40 metros, nível freático raso (menor que 10 metros) ou áreas de recarga aqüífera de extrema e alta vulnerabilidade natural à poluição.

Zona II - Restrição e controle: envolve áreas de aqüífero sedimentar poroso semipermeável, declividades entre 12 e $30 \%$, energia do relevo entre 41 e 80 metros, profundidade do nível freático entre 11 e 20 metros ou áreas de média ou baixa vulnerabilidade natural dos aqüíferos. 
Zona III - Baixa restrição: abrange estruturas rochosas praticamente impermeáveis como os aqüitardes, declividades entre 30 e $47 \%$, energia do relevo entre 81 e 120 metros, profundidade do nível freático de 21 a 30 metros ou áreas de baixa vulnerabilidade natural ou desprezível.

Zona IV - Prevenção: abarca áreas do sistema aqüífero fissural, declividades maiores que $47 \%$, energia de relevo maior que 121 metros, nível freático profundo (maior que 30 metros) e/ou que apresentam qualquer tipo de vulnerabilidade natural.

Zona V - Influência direta dos cursos de água: áreas que podem tornar-se fontes de contaminação das águas subterrâneas, sob certas condições hidrogeológicas e em função de serem utilizadas para a disposição final de águas residuais e resíduos sólidos de diversas origens, eventualmente podem até exceder a capacidade natural de depuração dos cursos de água. Assim, além do próprio leito do rio adota-se uma área de $30 \mathrm{~m}$ do leito que deve ser de preservação permanente, conforme previsto no Código Florestal (Lei n 4771 de 15/09/1965).

Após determinar as cinco Zonas de Proteção dos Aqüíferos elaborou-se uma proposta de restrição de atividades ou empreendimentos e estabeleceram-se condições de uso e ocupação do solo para a microbacia hidrográfica do Arroio Ferreira, considerando as limitações de cada Zona, quanto sua capacidade de ser afetada por uma carga contaminante imposta, bem como as legislações que definem os procedimentos à execução do licenciamento ambiental de cada atividade.

Nesta proposta foram consideradas as atividades sujeitas ao licenciamento ambiental que já estão instaladas na microbacia (devendo eventualmente adaptar-se aos critérios estabelecidos pelos órgãos ambientais) além daqueles empreendimentos que poderão a vir ser instalados.

\section{PROCEDIMENTOS TÉCNICOS}

\section{Delimitação da microbacia}

Para delimitação da área e construção de todos os mapas temáticos, utilizou-se a Carta Topográfica de Santa Maria, SH. 22-V-C-IV-1; MI - 2965/1, em escala 1:50.000, edição de 1971 e 1980, elaborada pela Diretoria do Serviço Geográfico do Exército Brasileiro (DSG).

Delimitou-se a área da microbacia identificando- se os divisores de águas a partir da análise do relevo e dos afluentes, convergência das águas para o rio principal e as curvas de nível de maior altitude interna e externamente à microbacia. A partir dessa delimitação elaboraram-se os Mapas de Energia do Relevo, Declividade, Geológico, Profundidade da Água Subterrânea, Vulnerabilidade Natural, Uso e Ocupação do Solo e Zonas de Proteção dos Aqüíferos.

\section{Geração dos Mapas Temáticos}

Todos os mapas gerados foram georreferênciados com o uso do programa Spring 6.0 no sistema de coordenadas UTM (Universal Transversa de Mercator), no fuso 22 Sul, com origem da quilometragem no Equador e Meridiano Central de 51WGr (acrescidas das constantes $10000 \mathrm{~km}$ e $500 \mathrm{~km}$, respectivamente), datum horizontal SAD-69, Córrego Alegre/Minas Gerais e datum vertical Imbituba, Santa Catarina.

\section{Mapa de Energia do Relevo}

Quando se utiliza a variável altitude, de certa maneira refere-se à energia do relevo, que se desenvolve a partir dos estudos ou da aplicação dos desvios existentes nas altitudes de uma área, relacionadas com a altitude padrão. Para elaboração da carta de energia relativa do relevo, Cunha (1988) estabeleceu uma metodologia própria em diferentes escalas, concluindo que a melhor figura geométrica para elaborar essa carta é o hexágono.

Portanto, para a construção deste mapa sobrepôs-se à carta topográfica de Santa Maria uma delimitação da microbacia hidrográfica do Arroio Ferreira e uma malha composta por células de formato hexagonal, com $1 \mathrm{~cm}$ de diâmetro cada; posteriormente, estabeleceu-se a amplitude altimétrica em cada célula a partir das curvas de nível inseridas na mesma (DE BIASI, 1970). Na seqüência, pela aplicação da regra de Sturges identificaram-se quatro classes de energia do relevo (<40m, 41-80m, 81-120m, >121m), que deram origem ao Mapa de Energia do Relevo da microbacia hidrográfica.

Essa variável está relacionada com a capacidade de transporte de massa em razão da ação do escoamento superficial, que em alguns casos, retira a camada não saturada do solo, expõem as áreas de recarga aqüífera ou submete o solo à erosão. A relação estabelecida entre a energia do relevo e os aqüíferos, consta no Quadro 1. 
DUTRA, D. A. et al. Plano de proteção de aqüíferos a partir de variáveis ambientais

\begin{tabular}{|l|l|}
\hline Classes de energia do relevo & Relação com os aqüiferos \\
\hline$<40 \mathrm{~m}$ & $\begin{array}{l}\text { São áreas com baixa energia, menor capacidade de transporte de massa e } \\
\text { favorecem a infiltração. }\end{array}$ \\
\hline $41-80 \mathrm{~m}$ & $\begin{array}{l}\text { Pode ocorrer lixiviação dos solos e das estruturas rochosas expondo a camada não } \\
\text { saturada. }\end{array}$ \\
\hline $81-120 \mathrm{~m}$ & $\begin{array}{l}\text { Dependendo da estrutura rochosa e da cobertura vegetal pode haver menor } \\
\text { infiltração e/ou retirada da camada não saturada do solo e exposição das camadas } \\
\text { saturadas, aumentando assim a vulnerabilidade dos aqüiferos. }\end{array}$ \\
\hline$>121 \mathrm{~m}$ & $\begin{array}{l}\text { Áreas favoráveis à erosão, devido à alta capacidade de transporte de massa; além } \\
\text { disso, há baixa infiltração. }\end{array}$ \\
\hline
\end{tabular}

QUADRO 1 - RELAÇÃO DA ENERGIA DO RELEVO COM A RECARGAAQÜÍFERA

FONTE: Elaborado pelos autores.

\section{Mapa de Declividade}

A partir da carta topográfica de Santa Maria em escala 1:50.000 e aplicação do método De Biasi (1970), obteve-se cinco classes de declividade $(<5 \%, 5-12 \%$, $12-30 \%, 30-47 \%$ e >47\%) para a microbacia hidrográfica do Arroio Ferreira.

A declividade é entendida como a inclinação do relevo em relação à linha do horizonte, ou como sendo a tangente trigonométrica da inclinação de uma linha no relevo relacionada com a linha do horizonte (DUARTE, 1988). Portanto, ela exerce significativa influência nas formas de uso da terra e na velocidade de escoamento superficial.

Entre as características do relevo, a declividade é de suma importância e de influência direta na formação e desenvolvimento dos solos, determinando desde o escoamento superficial até a infiltração da água no terreno. Dessa forma, Audi (1970), Herz e De Biasi (1989) estabeleceram classificações adequando o uso e ocupação do espaço de acordo com as classes de declividades (Quadro 2). A influência delas na recarga aqüífera foi estabelecida a partir de observações empíricas na área estudada.

\begin{tabular}{|c|c|c|c|}
\hline $\begin{array}{l}\text { Declivi } \\
\text { dades }\end{array}$ & $\begin{array}{l}\text { Classificação } \\
\text { Audi }(1970)\end{array}$ & $\begin{array}{l}\text { Classificação } \\
\text { Herz e De Biasi (1989) }\end{array}$ & $\begin{array}{l}\text { Influência na recarga aqüífera } \\
\text { (organizado pelos autores) }\end{array}$ \\
\hline$<5 \%$ & $\begin{array}{l}\text { Áreas praticamente } \\
\text { planas, declives } \\
\text { suaves, fácil para } \\
\text { práticas agrícolas, } \\
\text { mas requer práticas } \\
\text { simples de } \\
\text { conservação. }\end{array}$ & $\begin{array}{l}\text { Limite urbano industrial, utilizados } \\
\text { internacionalmente, bem como em trabalhos } \\
\text { de planejamento urbano efetuados pelo } \\
\text { Instituto de Pesquisas Tecnológicas do } \\
\text { Estado de São Paulo e da Empresa } \\
\text { Metropolitana de Planejamento da Grande } \\
\text { São Paulo. }\end{array}$ & $\begin{array}{l}\text { Observou-se lento escoamento } \\
\text { superficial, fato que proporciona } \\
\text { maior infiltração das águas das } \\
\text { chuvas e águas residuais. As } \\
\text { taxas de infiltração dependem } \\
\text { das condições hidrogeológicas } \\
\text { da área. }\end{array}$ \\
\hline $5-12 \%$ & $\begin{array}{l}\text { Áreas com declives } \\
\text { moderados, são } \\
\text { necessários alguns } \\
\text { cuidados como } \\
\text { terraceamento. }\end{array}$ & $\begin{array}{l}\text { Este limite possui algumas variações quanto } \\
\text { ao máximo a ser estabelecido (12\%), pois } \\
\text { alguns autores adotam cifras de } 10 \% \text { e ou } \\
13 \% \text {. A diferença é muito pequena, pois esta } \\
\text { faixa define o limite máximo do emprego de } \\
\text { mecanização da agricultura. }\end{array}$ & $\begin{array}{l}\text { A taxa de infiltração observada } \\
\text { é mais lenta que o escoamento } \\
\text { superficial, porém em locais } \\
\text { onde há terraceamento ocorre } \\
\text { um equilibrio entre ambos. }\end{array}$ \\
\hline $12-30 \%$ & $\begin{array}{l}\text { São áreas com } \\
\text { fortes declives, e } \\
\text { são inadequadas a } \\
\text { práticas agricolas. }\end{array}$ & $\begin{array}{l}\text { O limite de } 30 \% \text { é definido por Legislação } \\
\text { Federal - Lei } 6766 / 79 \text { - também chamada de } \\
\text { Lei Lehman, que define o limite máximo para } \\
\text { a urbanização sem restrições, a partir do qual } \\
\text { toda e qualquer forma de parcelamento far-se- } \\
\text { á através de exigências específicas. }\end{array}$ & $\begin{array}{l}\text { Nestas áreas o escoamento } \\
\text { superficial foi maior do que a } \\
\text { taxa de infiltração, todavia esta } \\
\text { ainda ocorre, porém em escala } \\
\text { menor do que nas classes de } \\
\text { declividade anteriores. }\end{array}$ \\
\hline $30-47 \%$ & $\begin{array}{l}\text { Áreas destinadas a } \\
\text { pastagens e } \\
\text { florestas, exigindo } \\
\text { práticas de } \\
\text { conservação. }\end{array}$ & $\begin{array}{l}\text { O Código Florestal fixa o limite de } 25^{\circ}(47 \%) \\
\text { como limite máximo de corte raso de florestas, } \\
\text { a partir do qual a exploração só será permitida } \\
\text { se sustentada por planos de manejo das } \\
\text { coberturas florestais, Lei n. } .^{\circ} .4771 / 65 \text { de } \\
15 / 09 / 65 \text {. }\end{array}$ & $\begin{array}{l}\text { Em áreas de pastagens } \\
\text { predomina o escoamento } \\
\text { superficial e nos locais de } \\
\text { cobertura vegetal o } \\
\text { escoamento superficial é menor } \\
\text { e se dá infiltração indireta, ou } \\
\text { seja, por meio das raizes das } \\
\text { plantas. }\end{array}$ \\
\hline$>47 \%$ & $\begin{array}{l}\text { Terras } \\
\text { aproveitáveis como } \\
\text { florestas, } \\
\text { aconselhável a } \\
\text { prática do } \\
\text { reflorestamento. }\end{array}$ & $\begin{array}{l}\text { O Art. } 10 \text { do Código Florestal prevê que uma } \\
\text { faixa situada entre } 25^{\circ}(47 \%) \text { e } 45^{\circ}(100 \%), \\
\text { "não é permitido a derrubada de florestas, }(\ldots) \\
\text { só sendo tolerada a extração de toras, quando } \\
\text { em regime de utilização racional, que vise } \\
\text { rendimentos permanentes". }\end{array}$ & $\begin{array}{l}\text { Áreas com intenso escoamento } \\
\text { superficial, por isso há } \\
\text { necessidade de exercer } \\
\text { práticas de reflorestamento } \\
\text { visando a proteção das } \\
\text { encostas e das áreas de } \\
\text { recarga. }\end{array}$ \\
\hline
\end{tabular}

QUADRO 2 - CLASSIFICAÇÃO DO TERRENO CONFORME AS DECLIVIDADES 


\section{Mapa Geológico}

O mapa geológico da microbacia do Arroio Ferreira foi gerado a partir da digitalização do Mapa Geológico da Folha de Santa Maria, escala 1:50.000 elaborada por Gaspareto et al. (1990).

Foram identificadas as formações geológicas oriundas do Quaternário (Sedimentos Atuais e Terraços
Fluviais), Formação Serra Geral (Seqüência Superior e Inferior), Formação Botucatu, Formação Caturrita, Formação Santa Maria (Membro Alemoa e Membro Passo das Tropas) e Formação Rosário do Sul. As características geológicas estão diretamente relacionadas com as condições hidrodinâmicas dos aqüíferos, conforme demonstra o Quadro 3.

\begin{tabular}{|c|c|c|c|}
\hline \multirow{2}{*}{\multicolumn{2}{|c|}{$\begin{array}{l}\text { Formação } \\
\text { Geológica } \\
\text { Sedimentos } \\
\text { Atuais }\end{array}$}} & Litologias & Comportamento hidroestratigráfico \\
\hline & & $\begin{array}{l}\text { Cascalhos, areias, siltes e argilas } \\
\text { fluviais }\end{array}$ & Corresponde a um aqüífero livre. \\
\hline \multicolumn{2}{|c|}{$\begin{array}{l}\text { Terraços } \\
\text { Fluviais }\end{array}$} & $\begin{array}{l}\text { Conglomerados, arenitos médios } \\
\text { argilosos, com estratificação cruzada } \\
\text { e planar, siltitos arenosos de cores } \\
\text { cinza-clara, rosa e amarela, de } \\
\text { ambiente fluvial. }\end{array}$ & $\begin{array}{l}\text { É um aqüífero de pouca importância, a } \\
\text { alimentação desse aqüífero se processa por } \\
\text { infiltração da água da chuva e indiretamente, por } \\
\text { drenância profunda a partir dos aqüíferos com } \\
\text { os quais estão em contatos. }\end{array}$ \\
\hline \multirow{2}{*}{$\begin{array}{l}\text { Serra } \\
\text { Geral }\end{array}$} & $\begin{array}{l}\text { Seqüência } \\
\text { Superior }\end{array}$ & $\begin{array}{l}\text { Rochas vulcânicas ácidas: riolitos } \\
\text { granofíricos de cor cinza-clara a } \\
\text { média e vitrófiros de cor preta ou } \\
\text { castanha subordinados, com } \\
\text { disjunção tabular dominante. }\end{array}$ & $\begin{array}{l}\text { Aqüíferos com permeabilidades de fissuras e } \\
\text { com baixa produção, pois elas são mais } \\
\text { espaçadas, diminuindo assim a capacidade de } \\
\text { armazenamento e a permeabilidade do maciço } \\
\text { como um todo. A infiltração se processa através } \\
\text { do solo residual. }\end{array}$ \\
\hline & $\begin{array}{l}\text { Seqüência } \\
\text { Inferior }\end{array}$ & $\begin{array}{l}\text { Rochas vulcânicas básicas: basaltos } \\
\text { e andesitos toleíticos de cor cinza- } \\
\text { escuro com intercalações de arenito } \\
\text { eólico. }\end{array}$ & $\begin{array}{l}\text { O basalto se comporta como aqüífero fraturado, } \\
\text { a circulação da água se da através das } \\
\text { superfícies de descontinuidades, quando não } \\
\text { preenchidas por mineralizações secundárias } \\
\text { com diâmetro efetivo suficiente a possibilitar o } \\
\text { fluxo da água. }\end{array}$ \\
\hline \multicolumn{2}{|c|}{ Botucatu } & $\begin{array}{l}\text { Arenitos médios a finos, de cor rosa } \\
\text { com estratificação cruzada } \\
\text { cuneiforme de grande porte de } \\
\text { ambiente eólico. }\end{array}$ & $\begin{array}{l}\dot{E} \text { um excelente aqüífero, apresenta } \\
\text { permeabilidade alta, bem como seus solos } \\
\text { residuais. Sua alimentação se processa por } \\
\text { infiltração através do solo na área de } \\
\text { afloramento, enquanto a recarga indireta ocorre } \\
\text { por drenância descendente a partir dos } \\
\text { derrames de basalto. }\end{array}$ \\
\hline \multicolumn{2}{|c|}{ Caturrita } & $\begin{array}{l}\text { Arenitos médios e finos róseos, com } \\
\text { estratificação cruzada, acanalada e } \\
\text { planar, intercalados com siltitos } \\
\text { vermelhos de ambiente fluvial, com } \\
\text { troncos vegetais fósseis silicificados. }\end{array}$ & $\begin{array}{l}\text { É formada por aqüíferos, camada } \\
\text { semipermeável e impermeável. A alimentação } \\
\text { do aqüífero se processa na área de afloramento, } \\
\text { por infiltração do solo ou por drenância } \\
\text { descendente a partir do Botucatu }\end{array}$ \\
\hline \multirow[b]{2}{*}{$\begin{array}{l}\text { Santa } \\
\text { Maria }\end{array}$} & $\begin{array}{l}\text { Membro } \\
\text { Alemoa }\end{array}$ & $\begin{array}{l}\text { Siltitos argilosos maciços, de cor } \\
\text { vermelha com níveis esbranquiçados } \\
\text { de concreções calcárias, ambiente de } \\
\text { sedimentação controvertido (lacustre, } \\
\text { loess). }\end{array}$ & $\begin{array}{l}\text { É praticamente impermeável, a parte superior } \\
\text { funciona como capa impermeável enquanto os } \\
\text { siltitos e arenitos argilosos da base são } \\
\text { semipermeáveis. A importância desta camada é } \\
\text { funcionar como selo isolante entre o que está } \\
\text { acima e abaixo dela, aqüiclude. }\end{array}$ \\
\hline & $\begin{array}{l}\text { Membro } \\
\text { Passo das } \\
\text { Tropas }\end{array}$ & $\begin{array}{l}\text { Arenitos feldspáticos grosseiros, com } \\
\text { estratificação cruzada, acanalada na } \\
\text { base, seguidos de siltitos arenosos } \\
\text { rocho-avermelhados de ambiente } \\
\text { fluvial, além de arenitos finos e siltitos } \\
\text { laminados de cor rosa a lilás, de } \\
\text { ambiente flúvio-lacustre. Impressões } \\
\text { de restos da flora Dicroidium. }\end{array}$ & $\begin{array}{l}\text { Essa camada é permeável e possui aqüífero } \\
\text { livre e/ou confinado. O nível freático do aqüífero } \\
\text { livre mantém-se por larga extensão abaixo da } \\
\text { camada impermeável sem haver confinamento. } \\
\text { À medida que se aprofunda torna-se confinado, } \\
\text { possuem produtividade muita elevadas. }\end{array}$ \\
\hline \multicolumn{2}{|c|}{ Rosário do Sul } & $\begin{array}{l}\text { Arenitos finos micáceos bem } \\
\text { consolidados de cor rosa a vermelha } \\
\text { na base, passando a amarelo- } \\
\text { acinzentada e lilás em direção ao } \\
\text { topo, com estratificação cruzada } \\
\text { acanalada e planar de origem fluvial. }\end{array}$ & $\begin{array}{l}\text { Possui permeabilidade moderada a baixa com } \\
\text { aqüíferos de baixa produção exploráveis por } \\
\text { poços escavados ou tubular por recarga indireta } \\
\text { pode receber água de outras formações. Nas } \\
\text { áreas de topografia baixa, o nível freático está } \\
\text { muito próximo à superfície. }\end{array}$ \\
\hline
\end{tabular}

QUADRO 3 - DESCRIÇÃO GEOLÓGICA E COMPORTAMENTO HIDROESTRATIGRÁFICO

FONTE: Adaptado de Gaspareto et al. (1990), Maciel Filho (1990) e CPRM (1994). 


\section{Mapa de profundidade da água subterrânea}

Nesta representação cartográfica, foram utilizados todos os tipos de poços (tubular ou cacimba) presentes na microbacia hidrográfica do Arroio Ferreira. Os dados foram obtidos a partir de consultas ao banco de dados do Sistema de Informações sobre Águas Subterrâneas (SIAGAS/CPRM), independente do tipo de aqüífero o qual captam água ou de sua profundidade. Utilizou-se o programa Surfer 6.0 e o modelo geoestatístico krigagem, na elaboração deste plano de informação.

\section{Mapa de vulnerabilidade natural dos aqüíferos}

Para o desenvolvimento do mapa de vulnerabilidade natural dos aqüíferos, aplicou-se o método "GOD" (FOSTER et al., 2003) a partir da verificação dos parâmetros Grau de confinamento hidráulico (ou condição do aqüífero ou ocorrência da água subterrânea); Ocorrência do substrato subjacente, ou características litológicas, ou grau de consolidação da zona não satura- da ou capas confinantes; e, Distância do nível da água subterrânea (em aqüíferos não confinados) ou teto do aqüífero (em aqüíferos confinados).

O índice final de vulnerabilidade obtido foi produto entre os valores atribuídos para cada um desses parâmetros, que correspondem às classes de vulnerabilidade natural (Desprezível ou Insignificante, Baixa, Média, Alta e Extrema) que o meio aqüífero apresenta ao ser afetado por uma carga contaminante (FOSTER et al., 2003).

Os valores atribuídos aos parâmetros considerados no método estão dispostos no Quadro 4, e seguiram a caracterização litológica e hidroestratigráfica das formações geológicas dispostas no Quadro 2, e a profundidade do nível da água foi obtido a partir do mapa de profundidade média do nível da água subterrânea. Salienta-se que dos 45 poços identificados na área apenas vinte seis continham as informações necessárias para aplicação do método "GOD".

\begin{tabular}{|c|c|c|c|c|c|c|c|}
\hline $\begin{array}{l}\text { Grau de } \\
\text { Confinamento } \\
\text { Hidráulico }\end{array}$ & $G$ & $\begin{array}{l}\text { Substrato } \\
\text { Litológico }\end{array}$ & 0 & $\begin{array}{l}\text { Distância } \\
\text { do nível } \\
\text { da água } \\
\text { (GOD) }\end{array}$ & $D$ & $\begin{array}{l}\text { Índice de } \\
\text { Vulnerabilidade }\end{array}$ & $\begin{array}{l}\text { Classe de } \\
\text { Vulnerabilidade }\end{array}$ \\
\hline Livre & 1,00 & $\begin{array}{l}\text { Sedimentos } \\
\text { Atuais }\end{array}$ & 0,80 & $5-20 m$ & 0,80 & 0,64 & Alta \\
\hline Livre & 1,00 & $\begin{array}{l}\text { Terraços } \\
\text { Fluviais }\end{array}$ & 0,55 & $5-20 m$ & 0,80 & 0,44 & Média \\
\hline Fissural & 0,70 & $\begin{array}{l}\text { Serra Geral } \\
\text { (Seq.Superior) }\end{array}$ & 0,65 & $5-20 m$ & 0,80 & 0,36 & Média \\
\hline Fissural & 0,70 & $\begin{array}{l}\text { Serra Geral } \\
\text { (Seq. Inferior) }\end{array}$ & 0,65 & $5-20 m$ & 0,80 & 0,36 & Média \\
\hline Livre & 1,00 & Botucatu & 0,80 & $5-20 m$ & 0,80 & 0,64 & Alta \\
\hline $\begin{array}{l}\text { Semi } \\
\text { Confinado }\end{array}$ & 0,40 & Caturrita & 0,75 & $5-20 m$ & 0,80 & 0,24 & Baixa \\
\hline Aqüiclude & 0,10 & $\begin{array}{l}\text { Santa Maria } \\
\text { (Membro } \\
\text { Alemoa) }\end{array}$ & 0,50 & $\begin{array}{l}5-20 m \\
20-50 m\end{array}$ & 0,75 & 0,04 & Desprezivel \\
\hline Livre & 1,00 & $\begin{array}{l}\text { Santa Maria } \\
\text { (Membro } \\
\text { Passo das } \\
\text { Tropas) }\end{array}$ & 0,75 & $\begin{array}{l}5-20 m \\
20-50 m\end{array}$ & 0,75 & 0,56 & Alta \\
\hline $\begin{array}{l}\text { Semi-Livre } \\
\text { Aqüitarde }\end{array}$ & 0,80 & Rosário do Sul & 0,75 & $\begin{array}{l}5-20 m \\
20-50 m\end{array}$ & 0,75 & 0,45 & Média \\
\hline
\end{tabular}

QUADRO 4 - VALORES INDICATIVOS DA VULNERABILIDADE DOS AQÜÍFEROS, ATRIBUÍDOS CONFORME O MÉTODO "GOD"

\section{Mapa de uso e ocupação do solo}

O mapa de uso e ocupação do solo da microbacia hidrográfica do Arroio Ferreira teve como base a imagem de satélite LANDSAT 7 TM, Bandas 3, 4 e 5, falsa cor, WRS=223/081BA, do dia 23/07/1994 na escala 1:50.000. As diferentes formas de ocupação desse espaço foram obtidas digitalizando-se as áreas equivalentes a áreas urbanas, solo exposto ou lavouras, campos, matas e superfícies cobertas por água. Para confirmação dessa interpretação realizaram-se trabalhos de campo. 


\section{Mapa das Zonas de Proteção dos Aqüíferos}

Este mapa foi gerado após a definição das cinco zonas de proteção que se basearam nas informações contidas nos mapas geológico, de vulnerabilidade natural, profundidade do nível da água, declividade e energia do relevo, os quais demonstram a realidade físico natural da microbacia hidrográfica.

\section{RESULTADOS E DISCUSSÕES}

\section{ASPECTOS FÍSICO-NATURAIS DA MICROBACIA HIDROGRÁFICA}

A microbacia hidrográfica do Arroio Ferreira insere-se numa zona de transição entre o Planalto Vulcânico e a Depressão Central Sul - Riograndense, onde são característicos os declives do Rebordo do Planalto, e ainda áreas dissecadas de relevo, com mais rugosidade topográfica nas bordas do Planalto, limítrofes com a Depressão Central.

O Rebordo do Planalto é considerado uma faixa transicional, constituído geologicamente pelas rochas efusivas básicas e ácidas e em menor escala pelos depósitos de tálus, diques e corpos tabulares de diabásio. A ocorrência de escarpas abruptas reflete o forte comando estrutural representado por falhamentos e diaclasamentos resultantes dos esforços de soergui- mentos do Planalto iniciados no Terciário (MÜLLER FILHO; SARTORI, 1999). Aparecem, também, no setor Norte da microbacia, extensões de rupturas bruscas caracterizando o Rebordo do Planalto, pela predominância das escarpas, vales encaixados e o processo de ravinamento, à medida que se aproxima da Depressão Central Sul-Riograndense. Essa por sua vez, surge de forma expressiva no Centro-Sul da microbacia, caracterizando-se geomorfologicamente por um relevo de coxilhas suaves, onde o principal processo está vinculado aos transportes de massa nas planícies aluviais existentes.

De acordo com o Mapa de Energia do Relevo (Figura 2) identifica-se a capacidade de transporte de massa no relevo expondo áreas de fragilidade, graças a ação do escoamento superficial, que está diretamente associada com a altitude do terreno, bem como áreas favoráveis a recarga do aqüífero, tornando-se fundamental às práticas de planejamento que identifiquem áreas impróprias à determinadas práticas agrícolas, à urbanização e à industrialização entre outras.

Predomina a classe de energia do relevo entre 0 e $40 \mathrm{~m}$, que representam $71,43 \%$ da área $(4.506,80 \mathrm{ha}$ ), abrange diferentes formações geológicas de caráter sedimentar; além da presença de vegetação secundária, matas ciliares, áreas com plantações e de solo exposto.

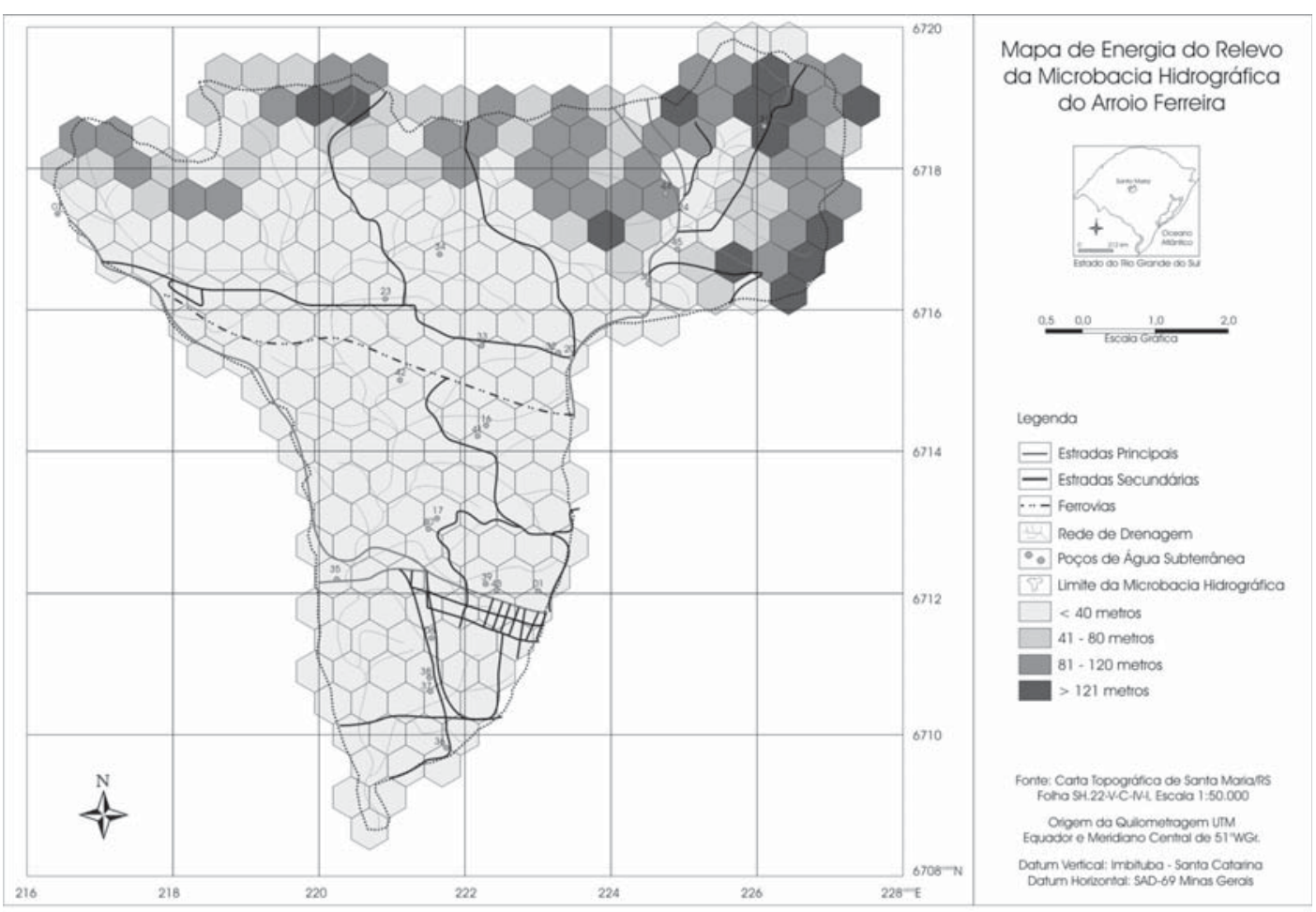

FIGURA 2 - MAPA DE ENERGIA DO RELEVO DA MICROBACIA HIDROGRÁFICA DO ARROIO FERREIRA 
A classe de energia do relevo entre 41 e $80 \mathrm{~m}$ abrange um total de 664,16ha, equivalente a $10,52 \%$ da microbacia, corresponde basicamente às declividades de 12 a 30\%, e é ocupada pelas áreas de matas ou florestas. O intervalo equivalente a 81-120 m totaliza-se em 830,2ha (13,16\%) da microbacia, abrangendo áreas das Formações Botucatu e Serra Geral, intercalando-se com solo exposto, vegetação secundária e florestas. A classe de energia do relevo maior que $121 \mathrm{~m}$ compreende 308,36 ha da área (4,89\%), atingem mais de 30\% de declividade e predominam áreas de floresta.

O Mapa de Declividade (Figura 3) revelou a presença de cinco classes, sendo que as áreas com até $5 \%$ de declividade ocupam $2.979,56$ ha ou $57,14 \%$ da microbacia, predominando no Centro-Sul da mesma. Esses locais são praticamente planos, com declives suaves e de fácil utilização para as práticas agrícolas, por isso destacam-se os campos e as culturas irrigadas (orizicultura e horticultura), além da urbanização. Visto que são áreas com drenagens sujeitas as inundações e início do limite da ação dos processos erosivos, requerem práticas simples de conservação e planejamento urbano.

As declividades entre 5 e $12 \%$, atingem 1.278,35ha cerca de $24,54 \%$ da microbacia; são caracterizados por declives moderados, dependendo da atividade exercida se faz necessário o terraceamento, pois estabelece o limite máximo no emprego da mecanização agrícola.

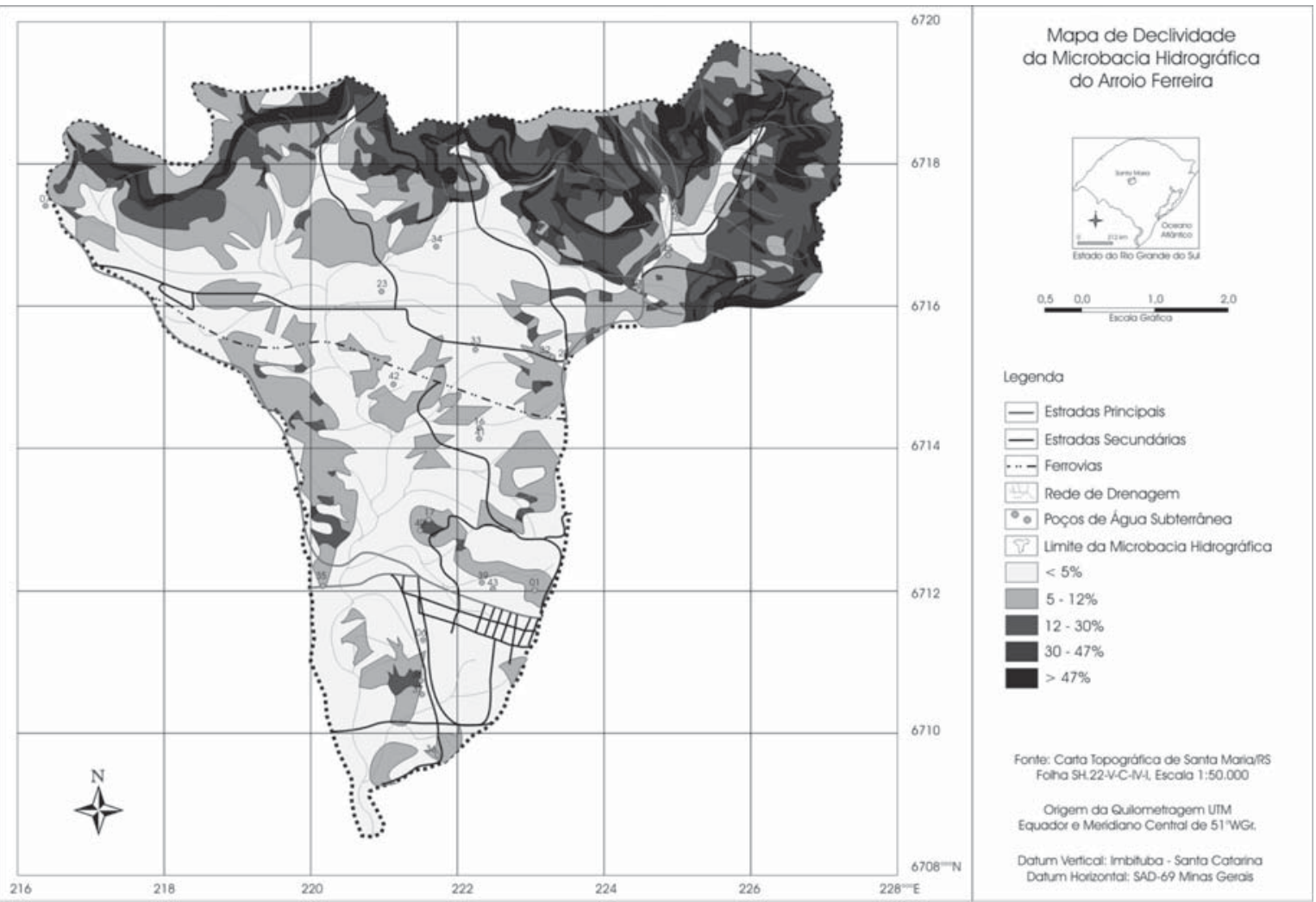

FIGURA 3 - MAPA DE DECLIVIDADES DA MICROBACIA HIDROGRÁFICA DO ARROIO FERREIRA

As áreas com fortes declives compreendem entre $12-30 \%$ de declividade predominam com o curso médio do rio principal. Equivalem a $10,99 \%$ da área e são consideradas inadequadas às práticas agrícolas, pois a ação dos processos erosivos é acelerada e exige cuidados especiais para esse uso. Identificou-se a presença de vegetação secundária e parte do estrato florestal.

As classes de declividade entre 30 e $47 \%$, e maior que $47 \%$ ocupam respectivamente $3,85 \%$ e $3,48 \%$ da microbacia do Arroio Ferreira, e localizam-se próximas as nascentes.

Associados aos fatores geomorfológicos, apresentam-se os fatores geológicos representados no Mapa Geológico da Microbacia (Figura 4). A partir desse, identificou-se quatro grupos de falhamentos com direção NW-SE que obedecem a um alinhamento principal variando de $30^{\circ}$ a $60^{\circ} \mathrm{NE}$, eventualmente tendo 
grande importância na infiltração das águas.

Em termos hidrogeológicos podem-se diferenciar dois sistemas aqüíferos, o Sistema Aqüífero Fissural e o Sistema Aqüífero Poroso. O primeiro, destaca-se com a Formação Serra Geral composta por duas seqüências vulcânicas: uma básica (seqüência inferior) e outra ácida (seqüência superior) em que o armazenamento da água se dá apenas nas falhas e fraturas da formação. A circulação restringe-se aos contatos entre as falhas ou por meio da ligação com as intercalações de sedimentação eólica, característicos registros dos períodos de recesso da atividade vulcânica, conhecidos como arenitos "intertrapps".

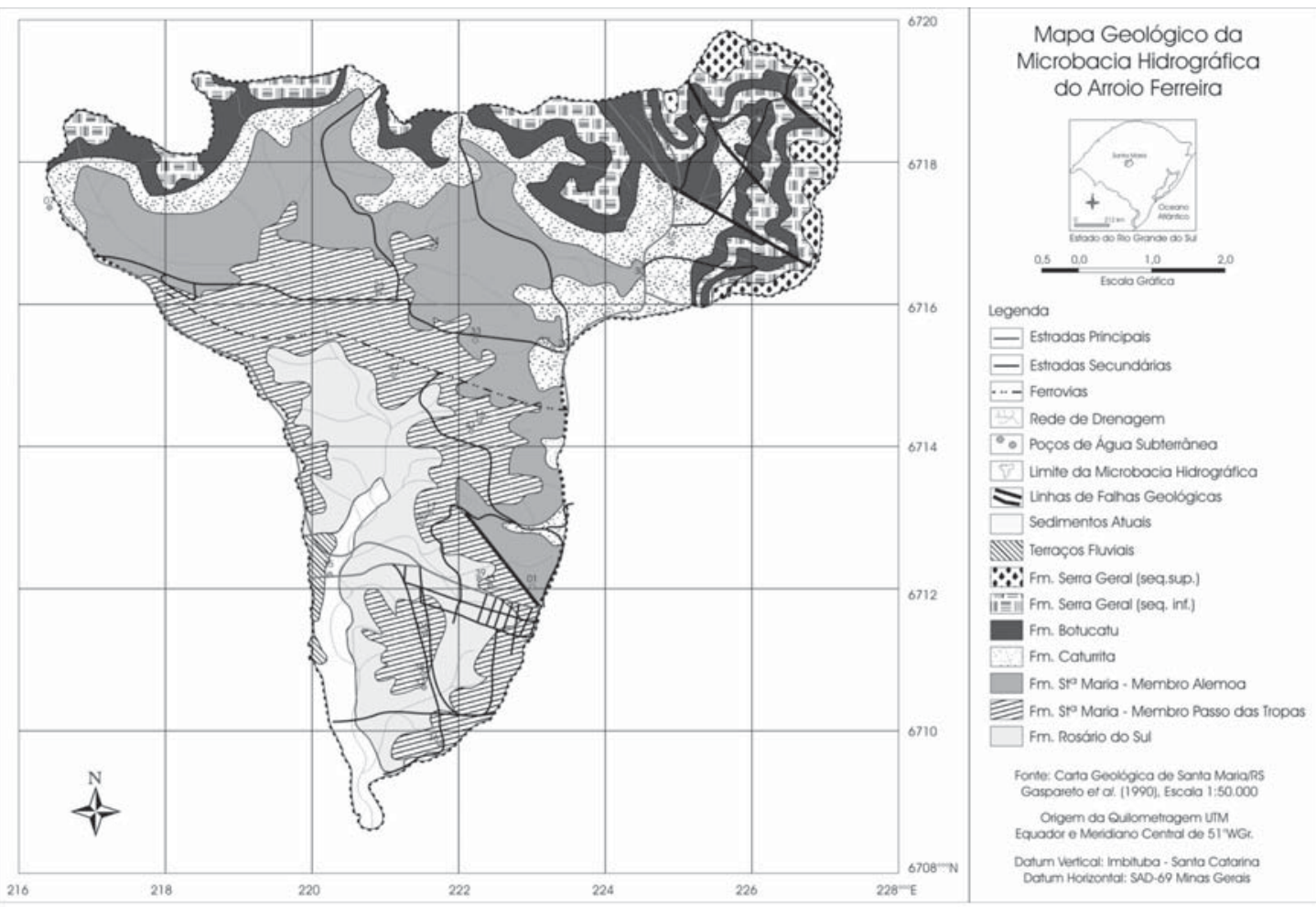

FIGURA 4 - MAPA GEOLÓGICO DA MICROBACIA HIDROGRÁFICA DO ARROIO FERREIRA

O Sistema Aqüífero Poroso está associado às rochas sedimentares que possuem granulações diferentes dependendo da natureza do sedimento (argilitos, siltitos e arenitos). Identificou-se, portanto, a Formação Botucatu que abrange 10,84\% da microbacia, a Formação Caturrita que constitui 13,90\% da área, a Formação Santa Maria - Membro Alemoa (22,39\%) e Membro Passo das Tropas (23,08\%), a Formação Rosário do Sul (15,06\%), além dos Sedimentos Quaternários e dos Terraços Fluviais que abrangem respectivamente 3,33\% e $0,48 \%$ da microbacia hidrográfica do Arroio Ferreira.

A geologia possui estreita relação com os solos, uma vez que eles originam-se diretamente do intemperismo das rochas. Na microbacia hidrográfica do Arroio Ferreira os solos desenvolvidos sobre rochas vulcânicas ácidas apresentam textura silto-arenosas ou silto-argilosa e espessuras de 1 a 3 metros, sendo classificado como Podzólicos vermelho-escuro ou Litólicos distróficos. Sobre as rochas básicas a variação de espessura é maior, sendo esses classificados como solos Litólicos eutróficos e Cambissolos eutróficos.

A espessura dos solos nas formações sedimentares variam de 1 a 2 metros alcançando até 5 metros na área de ocorrência do Membro Passo das Tropas da Formação Santa Maria, em que encontram-se os solos Podzólicos vermelho-escuro, Podzólicos vermelho-amarelo e Podzólicos acinzentados. Nas várzeas ocorrem Planossolos hidromórficos cinzentos e Cambissolos eutróficos (CPRM, 1994). 
A profundidade do nível da água subterrânea (Figura 5) na microbacia foi identificada a partir do nível estático dos poços, obtendo-se quatro classes de variação (<10m, 11-20m, 21-30m e > 30m de profundidade).

A profundidade da água subterrânea que predomina na microbacia é raso (menor que 10 metros) apresentando maior risco de contaminação, e segue uma direção SO-NE. Extrapola o limite da microbacia no setor Oeste em função da proximidade do Arroio Ferreira com o Arroio Taquara que convergem paralelamente para a mesma direção até unirem-se e formarem o Arroio Picadinho.

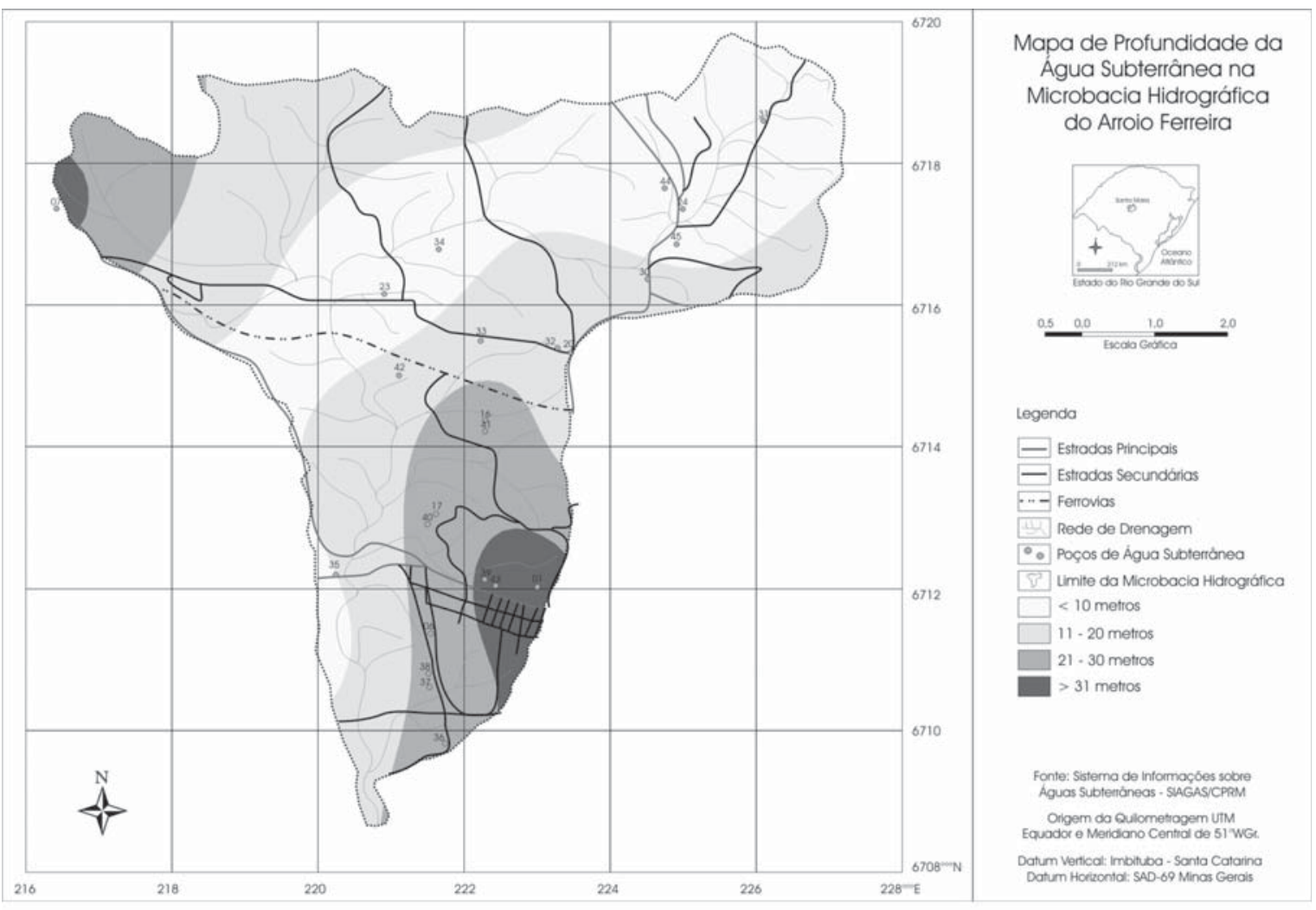

FIGURA 5 - MAPA DE PROFUNDIDADE DA ÁGUA SUBTERRÂNEA DA MICROBACIA HIDROGRÁFICA DO ARROIO FERREIRA

O nível da água subterrânea entre 11 e 20 metros aparece tanto ao Norte quanto ao Sul da classe anterior. As águas com profundidades entre 21 e 30 metros aparecem no setor Sudeste e atingem pequena extensão ao Noroeste da microbacia. O nível da água mais profundo (maior que 30 metros) abrange menor porcentagem da área e encontra-se no extremo Noroeste e Sudeste da microbacia.

A distância entre o nível da água subterrânea e a superfície do terreno é uma variável que associada com a litologia e ao tipo de aqüífero dá origem à condição de vulnerabilidade natural dos aqüíferos, ou seja, indica a fragilidade natural que o meio apresenta ao ser adversamente afetado por uma carga contaminante imposta (FOSTER et al., 2003).

A determinação da vulnerabilidade natural dos aqüíferos é importante para definição das áreas de proteção das águas subterrâneas. Assim elaborou-se o Mapa de Vulnerabilidade para a microbacia do Arroio Ferreira (Figura 6), com base no método "GOD" (FOSTER et al., 2003) e obteve-se a presença das classes de vulnerabilidade Alta, Média, Baixa e Desprezível. 


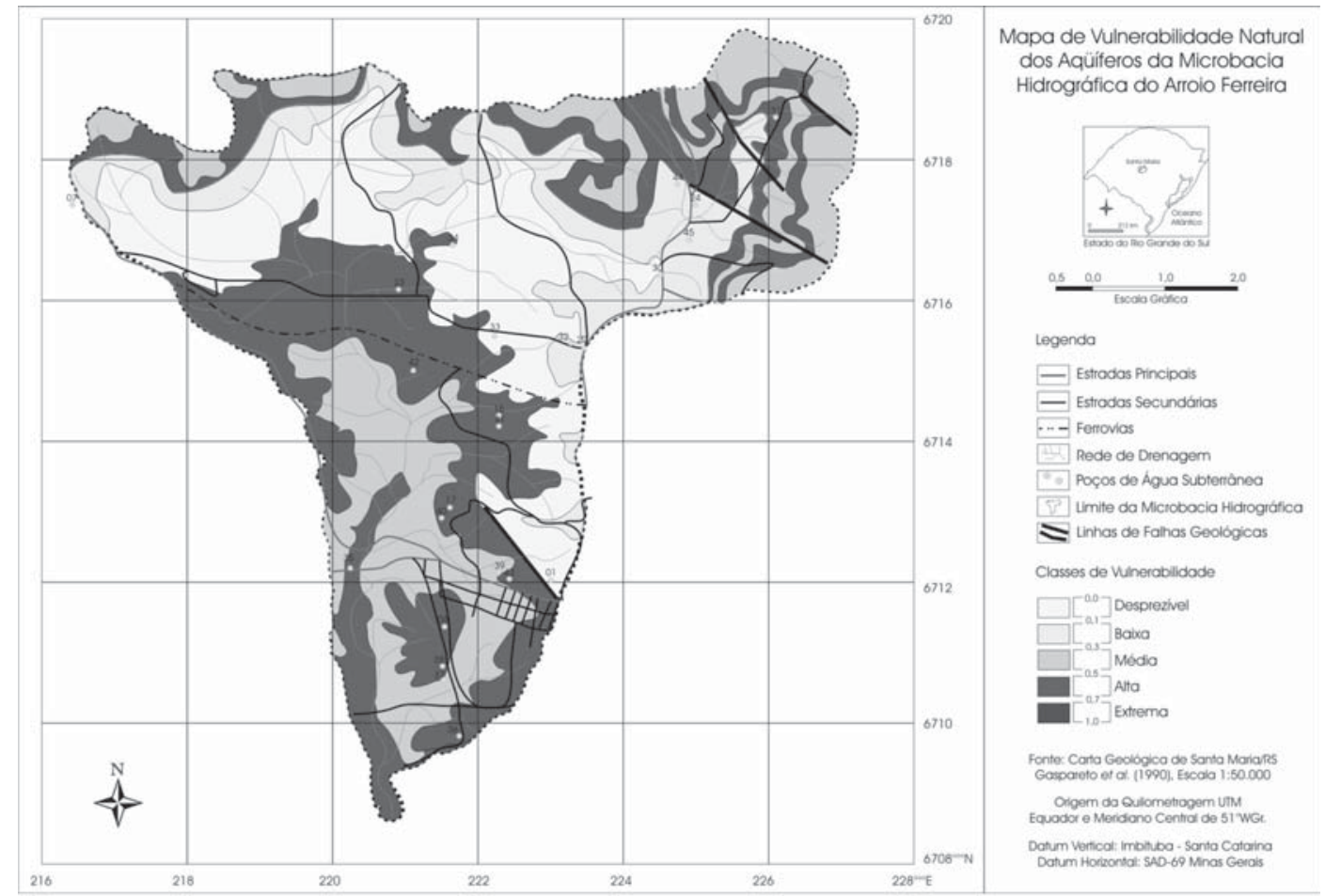

FIGURA 6 - MAPA DE VULNERABILIDADE NATURAL DOS AQÜÍFEROS DA MICROBACIA HIDROGRÁFICA DO ARROIO FERREIRA

A classe de vulnerabilidade Alta abrange maior extensão $(37,25 \%)$ seguida da classe Média $(26,46 \%)$ que aparece no Centro Sul, Norte e Nordeste da microbacia. A classe Desprezível envolve 22,39\% da área obedecendo a um sentido Sudeste - Noroeste. Ainda encontra-se a classe de vulnerabilidade Baixa, que compreende $13,90 \%$ e ocorre ao Norte da Classe Desprezível e em pequenas extensões no setor Leste.

Após analisar os aspectos físico-naturais da microbacia hidrográfica do Arroio Ferreira, indispensáveis para determinação das Zonas de proteção dos aqüíferos, foi necessário identificar as formas de uso e ocupação da área, a fim de propor sugestões de uso ou manejo das atividades que possam interferir na dinâmica quali-quantitativa das águas subterrâneas na microbacia.

\section{ASPECTOS SOCIOECONÔMICOS DA MICROBACIA HIDROGRÁFICA}

A microbacia do Arroio Ferreira possui um diversificado uso do solo (Figura 7), destacando-se áreas urbano residenciais, rurais, industrial, etc. No Centro-Sul destacam-se áreas agrícolas, ocupadas por culturas temporárias de arroz irrigado, cuja água utilizada é extraída diretamente do Arroio Ferreira, por meio de canalizações clandestinas e obstruções do curso principal do Arroio ou de poços tubulares profundos. A horticultura predomina no Distrito de Boca do Monte, Noroeste da microbacia, onde encontram-se estufas de legumes e verduras, além da produção leiteira. 


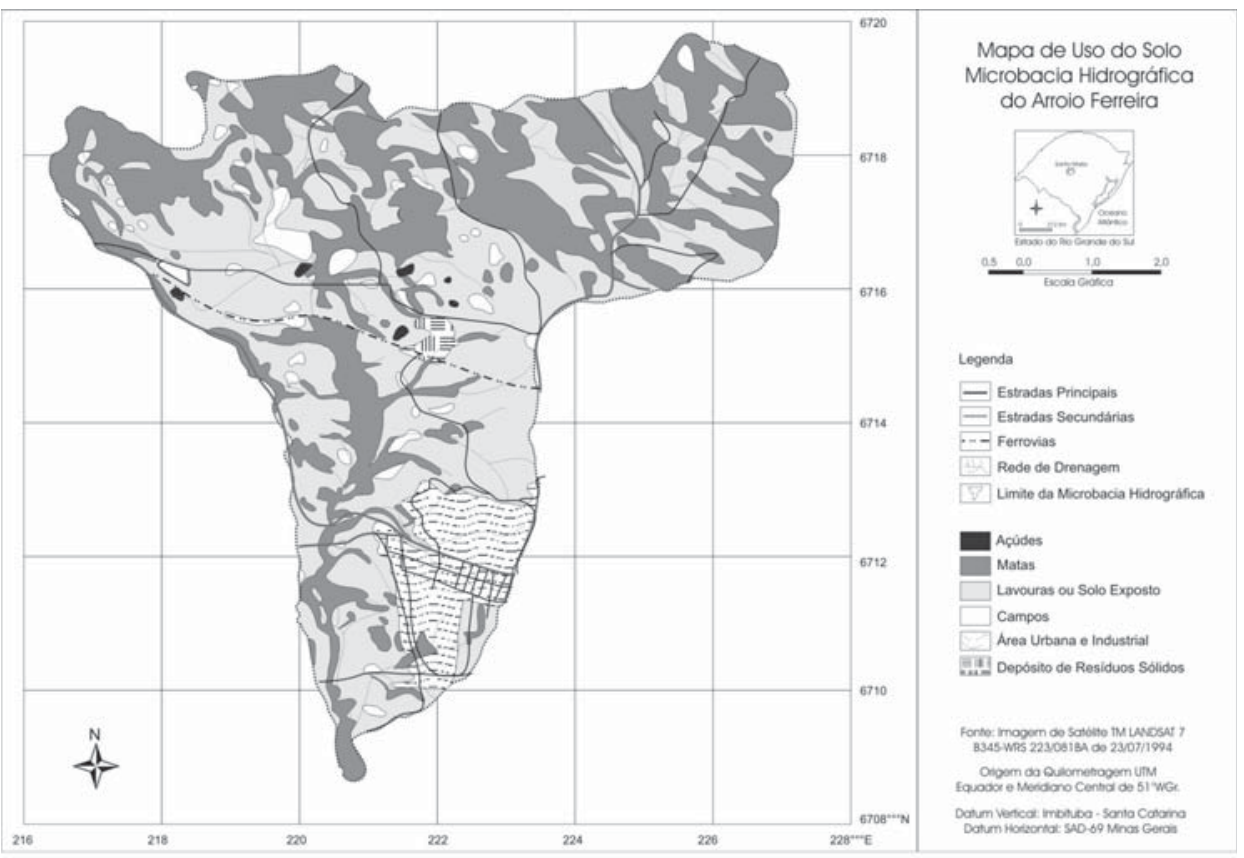

FIGURA 7 - MAPA DE USO DO SOLO DA MICROBACIA HIDROGRÁFICA DO ARROIO FERREIRA

Os campos ocupam $3.119,42$ ha, ou seja, $59,90 \%$; as matas compreendem $28,76 \%$ da área total (1.497,73ha); os solos expostos abrangem 185,90ha e correspondem a $3,57 \%$ da microbacia e os 14,06 ha restantes correspondem as superfícies de água (açudes e afluentes). As áreas urbanas abrangem $7,50 \%$ da área, ou seja, 390,57 ha envolvendo uma população superior a 30.000 pessoas (de acordo com os dados dos setores censitários, IBGE, 2000).

O processo de urbanização vem causando alterações no meio natural da microbacia, pois a cobertura vegetal está sendo substituída por superfícies que diminuem a infiltração e aumentam o escoamento superficial.

Tucci (1999) expõem que, o processo de urbanização provoca impactos como o aumento das vazões máximas (em até seis vezes), em razão do aumento da capacidade de escoamento por meio de condutos, canais e impermeabilização das superfícies; aumento da produção de sedimentos graças a desproteção das superfícies e a produção de resíduos sólidos (lixo); e por fim, deterioração da qualidade da água, graças à lavagem das ruas, transporte de material sólido e ligações clandestinas de esgoto cloacal e pluvial.

Um dos principais problemas urbano da microbacia estudada é a inexistência de sistemas de tratamento de esgotos na maioria dos bairros, sendo que as residências utilizam o sistema de fossas sépticas como forma de saneamento básico; verificou-se esse fato no Bairro Parque Pinheiro Machado, na Nova Santa Marta, no Distrito de Boca do Monte (região Noroeste da microbacia) e nas áreas de invasão, onde também é comum o uso de valas como destino final dos esgotos domésticos. O Bairro Tancredo Neves e a COHAB Santa Marta possuem sistema de coleta e tratamento simplificado de esgoto.

A população urbana em geral é abastecida por água canalizada e distribuída pela Companhia Riograndense de Saneamento - CORSAN, algumas residências são abastecidas por poços tubulares profundos ou poços tipo cacimba. No Distrito de Boca do Monte os moradores são servidos por águas subterrâneas que é extraída por dois poços tubulares profundos comunitários e destinadas para duas caixas de água centrais, onde recebem tratamento e são redistribuídas à comunidade como um sistema de condomínio, ou seja, cada família possui uma cota.

Nas proximidades do núcleo urbano da microbacia, identificaram-se dois postos de combustíveis, que podem ser considerados fontes pontuais de contaminação das águas subterrâneas e são relevantes para definição das zonas de proteção dos aqüíferos. Assim como a localização geográfica dos cemitérios em função da condição hidrogeológica do local em que estão 
dispostos e do tempo de funcionamento.

Outras fontes pontuais de contaminação das águas subterrâneas, associadas às atividades urbanas, foram identificadas na microbacia, como a deposição de resíduos sólidos (lixo) nas margens do Arroio Ferreira e seus afluentes. A presença do "Lixão de Santa Maria", localizado no centro dessa microbacia e a presença do Distrito Industrial.

O município de Santa Maria produz cerca de 150 toneladas diárias de resíduos sólidos (estimativas da Secretaria Municipal de Gestão Ambiental) depositados a céu aberto no denominado "Lixão da Caturrita", que se situa sobre rochas porosas e permeáveis, oriundas dos arenitos grossos da Formação Santa Maria - Membro Passo das Tropas e parte do Membro Alemoa (aqüiclude). Atinge um tributário de primeira ordem do Arroio Ferreira demonstrando que o lençol freático está com o nível localmente aflorante, alimentando o curso de água sazonalmente (DUTRA, 2001).

Segundo Machado (1990),

se não forem tomadas medidas preventivas, com a relocação desse depósito os efeitos negativos da contaminação das águas (superficiais ou subterrâneas) poderão levar alguns anos para serem percebidos, mas serão inexoráveis.

Em termos gerais, a indústria é o segundo maior consumidor de águas, e no Centro-Sul da microbacia localiza-se o Distrito Industrial de Santa Maria com indústrias de alimentos, bebidas, móveis, metal mecânica, construção civil, baterias, detergentes, etc. (DUTRA, 2001).

Todas as empresas inseridas no Distrito Industrial utilizam água subterrânea para realização de suas atividades, mas em apenas duas foram constatados métodos de tratamento dos efluentes.

\section{ZONAS DE PROTEÇÃO DOS AQÜÍFEROS}

Visando a gestão integrada dos recursos hídricos no âmbito da microbacia hidrográfica do Arroio Ferreira propôs-se um plano de proteção dos aqüíferos, em função dos aspectos físico-naturais e das atividades presentes na área, assim foi possível definir cinco Zonas de Proteção (Figura 8).

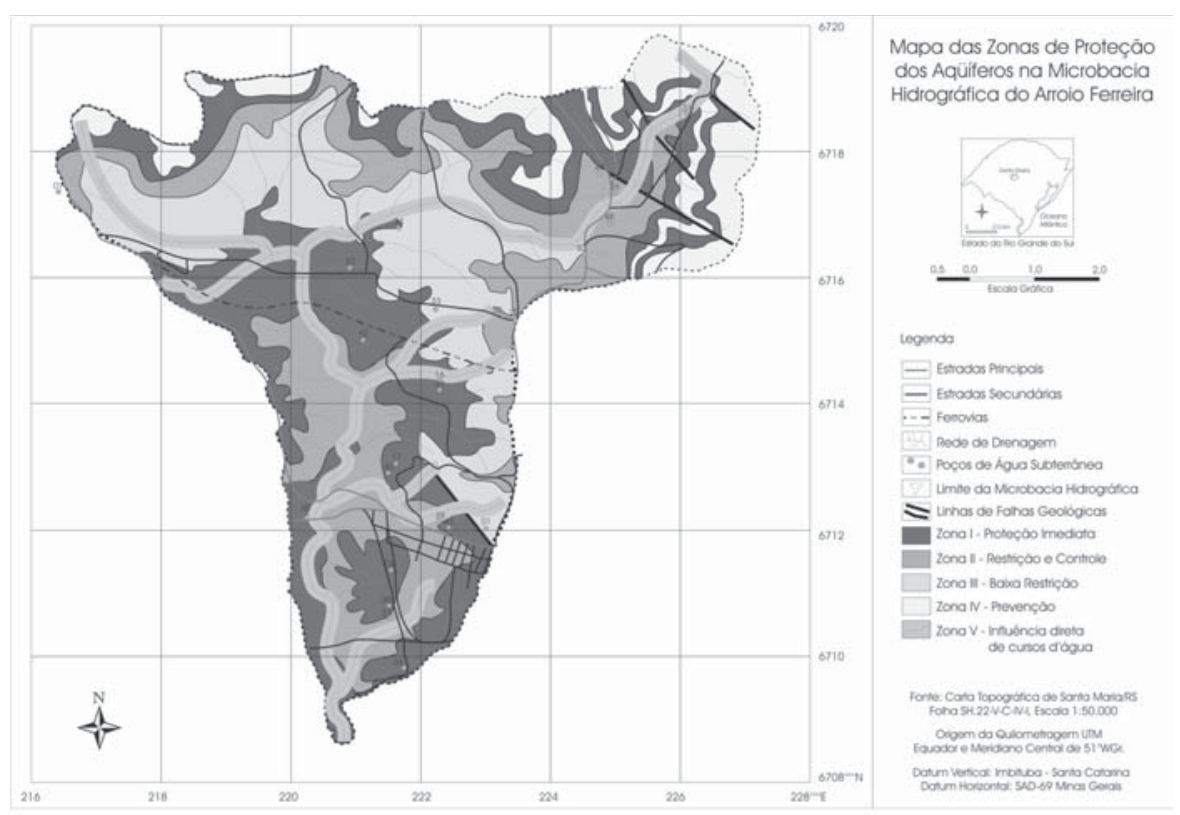

FIGURA 8 - MAPA DAS ZONAS DE PROTEÇÃO DOS AQÜÍFEROS NA MICROBACIA HIDROGRÁFICA DO ARROIO FERREIRA

A Zona de Proteção Imediata ocupa maior extensão da microbacia do Arroio Ferreira e compreende geologicamente os Sedimentos Atuais, os Terraços Fluviais, a Formação Botucatu e a Formação Santa Maria - Membro Passo das Tropas, áreas de vulnerabilidade natural alta, com baixas declividades e energia do rele- vo, além de diferentes profundidades do nível freático. Nessa zona encontram-se áreas urbanas, um cemitério, parte do Distrito industrial e do Lixão da Caturrita além de campos, lavouras e matas.

Os principais problemas de contaminação dos 
aqüíferos presentes nessa área estão associados às atividades do setor urbano-residencial, tais como os sistemas de saneamento sem rede de esgoto caracterizados como fontes de contaminação dispersa. Além disso, naqueles locais onde existe o sistema simplificado de esgoto, é possível verificar a ocorrência de rupturas e vazamentos dos tanques de inspeção. Salienta-se que essa carga contaminante poderia diminuir se houvesse empenho na construção de um sistema esgoto planejado e cuidadosamente operado.

A inadequada disposição dos resíduos sólidos é outra dificuldade, pois também é responsável pela contaminação das águas subterrâneas por meio da produção do lixiviado, cuja composição dependerá do tipo de material do resíduo ou da sua associação, que eventualmente podem originar reações químicas.

No caso dos cemitérios a contaminação é pontual e ocorre quando a sepultura de restos humanos ou de animais gera cargas contaminantes microbiológicas em uma restrita área atingindo, muitas vezes, uma pequena parcela do solo, sendo mais reduzida ainda, caso sejam utilizados nas tumbas impermeabilizantes especiais e/ ou cofres resistentes à corrosão.

A Zona de Restrição e Controle compreende os aqüíferos semipermeáveis como as Formações Caturrita e Rosário do Sul cuja vulnerabilidade natural à contaminação restringe-se as classes Média e Baixa. Essa zona também abrange uma significativa extensão da microbacia do Arroio Ferreira e envolve maior parcela dos Bairros Tancredo Neves e Parque Pinheiro Machado.

Nessas áreas residenciais estão instalados dois postos de combustíveis com possível presença de compostos tóxicos sintéticos, provenientes do armazenamento de combustíveis em tanques subterrâneos, o que tem sido uma das causas pontuais mais freqüentes de contaminação dos aqüíferos em áreas urbanas. Há uma alta probabilidade de que tanques instalados há mais de vinte anos estejam seriamente corroídos e sujeitos à fugas de substâncias, a menos que venham sendo monitorados periodicamente. Além disso, as tubulações entre os tanques e os sistemas de distribuição podem romper-se em razão do tráfego de veículos pesados e em função da má qualidade de instalação inicial das estruturas (FOSTER et al., 2003).

Também se encontram algumas indústrias nessa zona, cujas concentrações de contaminantes e algumas práticas de disposição de resíduos e efluentes fazem com que essas atividades sejam de grande preocupação ambiental na avaliação da carga contaminante.
É difícil estabelecer a proporção total do efluente que está se infiltrando no subsolo, pois as lagoas, poços de infiltração ou rios são também o destino final para os despejos industriais que muitas vezes são lançados sem nenhum tipo de tratamento prévio, o qual poderia diminuir seus efeitos nocivos (SILVA, 2003).

$\mathrm{Na}$ Zona de Baixa Restrição encontram-se as estruturas rochosas praticamente impermeáveis como os aqüicludes e aqüitardes da Formação Santa Maria Membro Alemoa, constituída por rochas sedimentares de cor avermelhada, sem textura, de caráter argiloso a síltico (lamito) com pequena ocorrência de depósitos de caliche e calcrete (concreções calcárias). As estruturas sedimentares primárias são predominantemente maciças, sem estratificações, localmente com estratificação plano-paralela. Em diversas fácies ocorre a interdigitação de lentes esbranquiçadas de siltitos com lentes de siltitos-vermelhos, o que lhe dá o caráter de aqüiclude (MACIEL FILHO, 1990).

Nessa Zona a vulnerabilidade natural é Desprezível, mas eventualmente pode apresentar valores de vulnerabilidade natural Baixa.

Quanto ao uso e ocupação, verifica-se nessa zona a presença do Lixão da Caturrita, áreas de solo exposto, matas e algumas práticas agrícolas apresentamse como potencialmente poluidoras graças às formas mecanizadas de manejo do solo em que há aplicação intensiva e prolongada de fertilizantes inorgânicos, assim como o uso de agrotóxicos. Soma-se a isso a irrigação excessiva do solo, que pode contribuir para o transporte e infiltração de nutrientes sais e traços de compostos orgânicos.

A Żona de Prevenção é recoberta predominantemente por matas em função da diferença altimétrica do relevo, que permanecem em torno de 30 - 47\%. Também aparecem em alguns locais as declividades entre 5-12\% e menor que $5 \%$, relativos aos relevos mais planos do planalto onde ocorre intercalação de lavouras e solos expostos. Nas áreas de maior diferença altimétrica a energia do relevo é maior que $121 \mathrm{~m}$, atingindo as classes de $81-120 m$ e $41-80 m$ nos locais de menor declividade. Essa área engloba as rochas vulcânicas pertencentes à Formação Serra Geral, onde o armazenamento de água se dá pelas fissuras, por isso definiram-se como zonas de vulnerabilidade Média.

Embora seja ocupada por atividades que não causam grandes impactos ao meio ambiente local e está associada às características morfoestruturais que dificultam a formação de um bom aqüífero, foi classificada como Zona de Prevenção porque os aqüíferos 
subjacentes podem receber contribuição das águas de superfície, por meio da percolação; assim deve-se prevenir a instalação de determinadas atividades na superfície dessa Zona que possam vir a prejudicar os aqüíferos subjacentes.

Por fim, a Zona de Influência Direta de Cursos de Áqua é frequentemente usada para a disposição final de águas residuais e resíduos sólidos de diversas origens, inclusive esgotos domésticos. Em muitos casos recebem altas cargas de efluentes não-tratados que excede a capacidade de depuração natural por muitos quilômetros a jusante. Segundo Foster e Hirata (1993) tais drenagens são convertidas em fontes de contaminação das águas subterrâneas, sob certas condições hidrogeológicas.

Para efetivar a proteção das águas subterrâneas sugerem-se algumas restrições e condições à implantação ou desenvolvimento de determinadas atividades humanas, bem como medidas de controle das fontes de poluição em cada área ou zona de proteção, conforme demonstra o Quadro 5.

\begin{tabular}{|c|c|c|c|c|c|}
\hline Atividades & $\begin{array}{l}\text { Zona I: } \\
\text { Proteção } \\
\text { imediata }\end{array}$ & $\begin{array}{l}\text { Zona II: } \\
\text { Restrição } \\
\text { e controle }\end{array}$ & $\begin{array}{l}\text { Zona III: } \\
\text { Baixa } \\
\text { restrição }\end{array}$ & $\begin{array}{l}\text { Zona IV: } \\
\text { Prevenção }\end{array}$ & \begin{tabular}{|l|} 
Zona V: \\
Influência \\
direta de \\
cursos d'água
\end{tabular} \\
\hline $\begin{array}{l}\text { Acesso às áreas } \\
\text { de proteção }\end{array}$ & \multicolumn{5}{|l|}{ Restrições } \\
\hline $\begin{array}{l}\text { Passagem de } \\
\text { pessoas }\end{array}$ & Permitido & Permitido & Permitido & Permitido & Permitido \\
\hline Agricultura & \multicolumn{5}{|l|}{ Condições } \\
\hline $\begin{array}{l}\text { Armazenamento } \\
\text { e aplicação de } \\
\text { fertilizantes } \\
\text { (orgânicos ou } \\
\text { inorgânicos) }\end{array}$ & Não permitido & Não permitido & \multicolumn{2}{|c|}{$\begin{array}{l}\text { Somente permitido de acordo com } \\
\text { os critérios estabelecidos pelos } \\
\text { órgãos ambientais. }\end{array}$} & Não permitido \\
\hline $\begin{array}{l}\text { Armazenamento } \\
\text { e aplicação de } \\
\text { agrotóxicos }\end{array}$ & Não permitido & Não permitido & \multicolumn{2}{|c|}{$\begin{array}{l}\text { Somente permitido quando estiver } \\
\text { de acordo com critérios } \\
\text { estabelecidos pelo órgão federal } \\
\text { ambiental, Decreto n`98.816/90 - } \\
\text { Cap. VII art. 59. Esta restrição } \\
\text { abrange os agrotóxicos } \\
\text { classificados como altamente ou } \\
\text { muito perigosos (classe I e II). }\end{array}$} & Não permitido \\
\hline $\begin{array}{l}\text { Armazenamento } \\
\text { e aplicação de } \\
\text { efluentes da } \\
\text { agroindústria }\end{array}$ & Não permitido & Não permitido & \multicolumn{2}{|c|}{$\begin{array}{l}\text { Permitido de acordo com os } \\
\text { critérios estabelecidos pela FEPAM. }\end{array}$} & Não permitido \\
\hline Irrigação & Não permitido & Não permitido & \multicolumn{2}{|c|}{$\begin{array}{l}\text { Somente permitido se não houver } \\
\text { aplicação de agrotóxicos. }\end{array}$} & Não permitido \\
\hline Pecuária & \multicolumn{5}{|l|}{ Condições } \\
\hline Criação extensiva & Não permitido & $\begin{array}{l}\text { Permitido, } \\
\text { desde que seja } \\
\text { com poucos } \\
\text { animais por } \\
\text { hectare. }\end{array}$ & Permitido & Permitido & Não permitido \\
\hline Criação intensiva & Não permitido & Não permitido & Permitido & $\begin{array}{l}\text { Permitido, } \\
\text { somente se o } \\
\text { pastoreio não } \\
\text { danificar a } \\
\text { cobertura vegetal. }\end{array}$ & Não permitido \\
\hline
\end{tabular}

QUADRO 5 - PROPOSTA DE RESTRIÇÕES E CONDIÇÕES DE USO E OCUPAÇÃO DO SOLO CONFORME AS LIMITAÇÕES DAS ZONAS DE PROTEÇÃO DOS AQÜÍFEROS 
DUTRA, D. A. et al. Plano de proteção de aqüíferos a partir de variáveis ambientais

Continuação

\begin{tabular}{|c|c|c|c|c|c|}
\hline $\begin{array}{l}\text { Armazenamento } \\
\text { de dejetos } \\
\text { animais em } \\
\text { estado líquido }\end{array}$ & Não permitido & Não permitido & \multicolumn{2}{|c|}{$\begin{array}{l}\text { Somente permitido de acordo com } \\
\text { os critérios estabelecidos pela } \\
\text { FEPAM }\end{array}$} & \multirow{2}{*}{\begin{tabular}{|l} 
Não permitido \\
Não permitido
\end{tabular}} \\
\hline $\begin{array}{l}\text { Instalações para } \\
\text { criação de } \\
\text { animais } \\
\text { confinados }\end{array}$ & Não permitido & Não permitido & Permitido & $\begin{array}{l}\text { Permitido somente } \\
\text { se o piso for } \\
\text { impermeabilizado }\end{array}$ & \\
\hline Desmatamentos & \multicolumn{5}{|l|}{ Condições } \\
\hline $\begin{array}{l}\text { Eliminação da } \\
\text { cobertura vegetal }\end{array}$ & Não permitido & Não permitido & Não permitido & Não permitido & Não permitido \\
\hline Resíduos Sólidos & \multicolumn{5}{|l|}{ Condições } \\
\hline $\begin{array}{l}\text { Aterro de resíduo } \\
\text { domiciliar }\end{array}$ & Não permitido & Não permitido & $\begin{array}{l}\text { Permitido, } \\
\text { obedecendo } \\
\text { aos critérios } \\
\text { estabelecidos } \\
\text { por legislação } \\
\text { Federal e } \\
\text { Estadual. }\end{array}$ & $\begin{array}{l}\text { Somente permitido } \\
\text { se o nível da água } \\
\text { estiver a mais de } \\
15 \mathrm{~m} \text { de } \\
\text { profundidade e se } \\
\text { não for aterro em } \\
\text { vala. } \\
\end{array}$ & Não permitido \\
\hline $\begin{array}{l}\text { Instalações para } \\
\text { compostagem de } \\
\text { resíduos } \\
\text { orgânicos }\end{array}$ & Não permitido & Não permitido & \multicolumn{2}{|c|}{$\begin{array}{l}\text { Permitido somente se o piso for } \\
\text { impermeabilizado. }\end{array}$} & Não permitido \\
\hline $\begin{array}{l}\text { Aterro de } \\
\text { resíduos da } \\
\text { saúde }\end{array}$ & Não permitido & Não permitido & \multicolumn{2}{|c|}{$\begin{array}{l}\text { Permitido desde que siga os } \\
\text { procedimentos necessários a } \\
\text { impermeabilização da superfície do } \\
\text { terreno. }\end{array}$} & Não permitido \\
\hline $\begin{array}{l}\text { Aterro de resíduo } \\
\text { industrial } \\
\text { (Classe I e II) }\end{array}$ & Não permitido & Não permitido & \multicolumn{2}{|c|}{$\begin{array}{l}\text { Permitido desde que obedeçam aos } \\
\text { procedimentos exigidos pela } \\
\text { FEPAM. }\end{array}$} & Não permitido \\
\hline $\begin{array}{l}\text { Aterro de resíduo } \\
\text { inerte e da } \\
\text { construção civil }\end{array}$ & Não permitido & Não permitido & \multicolumn{2}{|c|}{$\begin{array}{l}\text { Permitido deste que siga os } \\
\text { procedimentos de proteção do } \\
\text { terreno, incluindo a cobertura do } \\
\text { resíduo. }\end{array}$} & Não permitido \\
\hline $\begin{array}{l}\text { Efluentes e } \\
\text { matérias-primas } \\
\text { líquidas }\end{array}$ & \multicolumn{5}{|l|}{ Condições } \\
\hline $\begin{array}{l}\text { Estação de } \\
\text { tratamento de } \\
\text { esgoto }\end{array}$ & Não permitido & Não permitido & Permitido & Permitido & Não permitido \\
\hline Fossa séptica & Não permitido & Não permitido & \multicolumn{2}{|c|}{$\begin{array}{l}\text { Permitido deste que os lotes } \\
\text { atendam às restrições definidas no } \\
\text { item "loteamento" e as fossas sejam } \\
\text { construídas conforme as normas } \\
\text { NBR7229/93 e NBR13969/97. }\end{array}$} & Não permitido \\
\hline $\begin{array}{l}\text { Rede coletora de } \\
\text { esgoto }\end{array}$ & Não permitido & Não permitido & \multicolumn{2}{|c|}{$\begin{array}{l}\text { Permitido somente com } \\
\text { manutenção contra vazamentos. }\end{array}$} & Não permitido \\
\hline $\begin{array}{l}\text { Sistema de } \\
\text { tratamento de } \\
\text { água residuárias }\end{array}$ & Não permitido & Não permitido & \multicolumn{2}{|c|}{$\begin{array}{l}\text { Permitido somente com } \\
\text { manutenção contra vazamentos. }\end{array}$} & Não permitido \\
\hline
\end{tabular}

QUADRO 5 - PROPOSTA DE RESTRIÇÕES E CONDIÇÕES DE USO E OCUPAÇÃO DO SOLO CONFORME AS LIMITAÇÕES DAS ZONAS DE PROTEÇÃO DOS AQÜÍFEROS 


\begin{tabular}{|c|c|c|c|c|c|}
\hline $\begin{array}{l}\text { Armazenamento } \\
\text { e aplicação de } \\
\text { efluentes da } \\
\text { agroindústria e } \\
\text { indústria } \\
\text { alimentícia. }\end{array}$ & Não permitido & Não permitido & \multicolumn{2}{|c|}{$\begin{array}{l}\text { Permitido de acordo com os } \\
\text { critérios estabelecidos por órgãos } \\
\text { ambientais. As lagoas de } \\
\text { armazenamentos devem ser } \\
\text { impermeabilizadas e possuir dreno } \\
\text { testemunho. }\end{array}$} & Não permitido \\
\hline $\begin{array}{l}\text { Tratamento de } \\
\text { madeira com } \\
\text { substâncias } \\
\text { perigosas }\end{array}$ & Não permitido & Não permitido & $\begin{array}{l}\text { Somente permitido } \\
\text { se o nível da água } \\
\text { estiver a mais de } \\
20 \mathrm{~m} \text { de } \\
\text { profundidade. }\end{array}$ & Não permitido & Não permitido \\
\hline $\begin{array}{l}\text { Matérias primas e } \\
\text { combustiveis }\end{array}$ & \multicolumn{5}{|l|}{ Condições } \\
\hline $\begin{array}{l}\text { Tanques } \\
\text { enterrados }\end{array}$ & Não permitido & Não permitido & \multicolumn{2}{|c|}{ 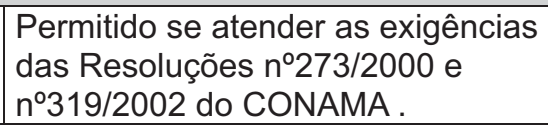 } & Não permitido \\
\hline $\begin{array}{l}\text { Bases de } \\
\text { distribuição de } \\
\text { combustíveis }\end{array}$ & Não permitido & Não permitido & \multicolumn{2}{|c|}{$\begin{array}{l}\text { Permitido se atender as exigências } \\
\text { das Resoluções } n^{\circ} 273 / 2000 \text { e } \\
n^{\circ} 319 / 2002 \text { do CONAMA }\end{array}$} & Não permitido \\
\hline Construção civil & \multicolumn{5}{|l|}{ Condições } \\
\hline Loteamento & Não permitido & Não permitido & \multicolumn{2}{|c|}{$\begin{array}{l}\text { Permitido em conformidade com as } \\
\text { exigências da FEPAM e Plano } \\
\text { Diretor Municipal. }\end{array}$} & Não permitido \\
\hline Indústrias & Não permitido & Não permitido & \multicolumn{2}{|c|}{$\begin{array}{l}\text { Permitido seguindo os critérios } \\
\text { estabelecidos em legislação } \\
\text { Federal e Estadual. }\end{array}$} & Não permitido \\
\hline Outras atividades & \multicolumn{5}{|l|}{ Condições } \\
\hline Cemitérios & Não permitido & Não permitido & \multicolumn{2}{|c|}{$\begin{array}{l}\text { Permitido somente os já existentes } \\
\text { sem ampliação ou se obedecer as } \\
\text { disposições da Resolução } \\
n^{\circ} 335 / 2003 \text { do CONAMA. }\end{array}$} & Não permitido \\
\hline
\end{tabular}

FONTE: ELABORADO PELOS AUTORES COM ADAPTAÇÕES DE DIAS ET AL. (2004).

QUADRO 5 - PROPOSTA DE RESTRIÇÕES E CONDIÇÕES DE USO E OCUPAÇÃO DO SOLO CONFORME AS LIMITAÇÕES DAS ZONAS DE PROTEÇÃO DOS AQÜÍFEROS

Com base na legislação vigente e nos estudos preliminares sobre zonas de proteção de poços, frente ao gerenciamento e proteção das águas subterrâneas, foi elaborada a proposta apresentada no Quadro 5, sobre as restrições de atividades e de uso do solo a serem aplicadas nas zonas de proteção aqüífera.

Essas restrições enfocam o controle ou mesmo proibição de novos empreendimentos possivelmente contaminantes das águas subterrâneas, sendo que as medidas são mais rígidas nas Zonas I, II e V, considerando sua condição natural de fragilidade.

Essa proposta tem por finalidade servir de base para a implantação de estratégias de proteção de aqüíferos. Sua efetivação depende da ação das prefeituras municipais e órgãos ambientais de todas as esferas (Federal, Estadual e Municipal), que têm atribuições sobre o parcelamento do solo e podem resguardar as áreas de proteção em seus planos diretores e ambientais, respectivamente.

\section{CONCLUSÃO}

De acordo com o exposto, verifica-se que a microbacia do Arroio Ferreira apresenta condições naturais propícias à contaminação dos recursos hídricos subterrâneos, além de fazer parte da área de recarga do Sistema Aqüífero Guarani; e os problemas associados à degradação dos corpos de água constatados, compreendem a falta de saneamento básico, lançamento de efluentes industriais não devidamente tratados e atividades agrícolas que além de provocar a poluição captam água para irrigação de forma errônea contribuindo para diminuição da disponibilidade hídrica local, 
os desmatamentos também provocam a degradação dos solos e o aparecimento de voçorocas deixando as águas subterrâneas mais susceptíveis a contaminações difusas ou pontuais.

A proposta dos critérios de restrição do uso e ocupação do solo em áreas de proteção para a microbacia hidrográfica do Arroio Ferreira e a definição das Zonas de proteção dos Aqüíferos, apresentadas neste trabalho serve de base para uma discussão mais ampla sobre estratégias que podem ser adaptadas para qualquer município ou comitê de bacia hidrográfica.

No caso de adaptações para outros locais, ressalta-se a necessidade de desenvolverem-se estudos particulares, pois cada bacia hidrográfica, município ou região apresentam particularidades que podem gerar resultados diferenciados, como mais ou diferentes Zonas de Proteção, Critérios de Uso do Solo e Restrições às atividades.

Conclui-se, portanto que, a preservação da quantidade e da qualidade da água subterrânea, tanto para esta como para as futuras gerações, depende não somente das ações dos profissionais da área, mas também de cada indivíduo da sociedade, por meio da aquisição de conhecimento básico. Este, por sua vez, permite uma transferência da conscientização sobre o tema para a população que pode resultar na preservação do recurso hídrico subterrâneo por ações individuais que, somadas podem gerar resultados expressivos.

\section{REFERÊNCIAS}

AUDI, R. Classificação dos solos em "classes de capacidade de uso", com o emprego de fotografias aéreas verticais. Caderno de ciência da Terra. n. 3. São Paulo: IGEO/USP,1970.

BRASIL. Secretaria de Planejamento da Presidência da República. Levantamento de Recursos Naturais. Mapa Geomorfológico do RS. Rio grande do Sul. Fundação IBGE, 1986. Escala 1:1.000.000. v. 33.

CHRISTOFOlETTI, A. Geomorfologia. 2. ed. São Paulo: Edgard Blücher, 1980. 188 p.

COELHO, V. M. T.; DUARTE, U. Perímetros de Proteção para fontes naturais de águas minerais. Revista Águas Subterrâneas. n.17 de 05/2003. Curitiba: ABAS, 2003.

CONAMA. Resolução n. 237 de 19 de dezembro de 1997. Expõem quais as atividades ou empreendimentos estão sujeitos ao licenciamento ambiental. Brasília 1997.

CONAMA. Resolução n. 258 de 26 de agosto de 1999. Dispõem sobre a destinação final, de forma ambientalmente adequada e segura aos pneumáticos inservíveis. Brasília, 1999.

CONAMA. Resolução n. 25730 de junho de 1999. Dispõe sobre o descarte inadequado de pilhas e baterias usadas. Brasília, 1999.

CONAMA. Resolução n. 284 de 30 de agosto de 2001. Dispõe sobre o licenciamento de empreendimentos de irrigação que podem causar modificações ambientais. Brasília, 2001.

CONAMA. Resolução n. 289 de 25 de outubro de 2001. Estabelece diretrizes para o licenciamento ambiental de projetos de assentamentos ou de reforma agrária. Brasília, 2001.

CONAMA. Resolução n. 307 de 05 de julho 2002. Estabelece diretrizes, critérios e procedimentos para a gestão dos resíduos da construção civil. Brasília, 2002.

CONAMA. Resolução n. 273 de 29 de novembro de 2000. Dispõem sobre o licenciamento ambiental de postos de combustíveis. Brasília, 2000.

CONAMA. Resolução n. 319 de 04 de dezembro de 2002. Dá nova redação e dispositivos da Resolução do CONAMAn. 273 de 29 de novembro de 2000. Brasília, 2002.

CONAMA. Resolução n. 335 de 03 de abril de 2003. Dispõem sobre o licenciamento ambiental de cemitérios. Brasília, 2003.

CONSEMA. Resolução n. 009 de 27 de dezembro de 2000. Dispõe de norma para o licenciamento ambiental de sistemas de incineração de resíduos provenientes de serviços de saúde, classificados como infectantes (Grupo A) e dá outras providências. Porto Alegre, 2000.

CPRM - Companhia de Pesquisas e Recursos Minerais. Mapa Hidrogeológico da Folha SH.22-V-C-IV (Mi 2965), Escala 1:100.000. 1994.

DE BIASI, M. A Carta Clinográfica: Os Métodos de Representação e sua Confecção. Revista do Departamento de Geografia. USP. p. 45-60, 1970 .

DIAS, C. L.; IRITANI, M. A.; GUILLAUMON, J. R.; CASARINI, D. C. P.; OKANO, O.; FERREIRA, L. M. R.; FRISCH, H.; TROEGER, U.; SCHULER, G. Restrições de uso e ocupação do solo em áreas de proteção de aqüíferos: conceitos, legislação e proposta de aplicação no estado de São Paulo. CONGRESSO BRASILEIRO DE ÁGUAS SUBTERRÃNEAS, 13. Anais... Cuiabá, 19 a 22 de outubro de 2004.

DUARTE, P. A. Cartografia Básica. 2. ed. Florianópolis: UFSC, 1988. 182 p. (Série Didática).

DUTRA, A. D. Uso dos Recursos Hídricos na Microbacia do Arroio Ferreira. Trabalho de Graduação (Geografia) - Curso de Graduação em Geografia, Universidade Federal de Santa Maria, Santa Maria, 2001.

DUTRA, A. D. Ações de Educação Ambiental na Microbacia Hidrográfica do Arroio Ferreira. Monografia (Curso de Especialização da Pós Graduação em Educação Ambiental) Universidade Federal de Santa Maria, Santa Maria, 2004.

FOSTER, S. S. D; HIRATA, R.; GOMES, D.; D'ELIA, M.; PARIS, M. Protección de la Calidad del Agua Subterránea. Washington: Banco Mundial, 2003. 116 p. 
DUTRA, D. A. et al. Plano de proteção de aqüíferos a partir de variáveis ambientais

FUNDAÇÃO INSTITUTO BRASILEIRO DE GEOGRAFIA E ESTATÍSTICA. Geografia do Brasil: Região Sul. Rio de Janeiro: IBGE, 1991. 420 p.

GASPARETO, N. V. L. et al. Mapa geológico de Santa Maria. Departamento de Geociências /UFSM. 1990.

HERZ, F.; DE BIASE, M. Critérios e Legendas para Macrozoneamento costeiro. Brasília: Comissão Interministerial para os Recursos do Mar, 1989.

MACIEL FILHO, C. L. Uma proposta para evitar a poluição por lixo e esgoto doméstico. Ciência e Natura. Santa Maria UFSM/CCNE, v. 10, p. 49-58, 1988.

. Carta Geotécnica de Santa Maria. Santa Maria: Imprensa Universitária, 1990. p. 11-13.

DIRETORIA DO SERVIÇO GEOGRÁFICO (Ministério do Exército) Carta Topográfica de Santa Maria-RS. Porto Alegre: DSG, 1976. Escala: 1:50.000. Folha SH-22-V-C-IV-1, MI-2965/1.

MOREIRA, I. O espaço Rio-Grandense. São Paulo: Ática,
1995, $96 \mathrm{p}$.

MÜLLER FILHO, I. L. M.; SARTORI, M. da. G. B. Elementos para Interpretação Geomorfológica de Cartas Topográficas: Contribuição à Análise Ambiental. Santa Maria: Imprensa Universitária - UFSM, 1999. 94 p.

PROJETO RADAMBRASIL (Fundação Instituto Brasileiro de Geografia e Estatística. RJ: FIBGE) Levantamento de recursos naturais. Porto Alegre: Geologia, 1986. v. 33. Folha SH. 22.

SILVA, A. de B. Sistemas de informações geo-referenciadas: conceitos e fundamentos. Campinas: Editora da UNICAMP, 2003. 240 p.

TUCCI, C. E. M. (Org.). Hidrologia: ciência e aplicação. Porto Alegre: ABRH/Edusp. 1993943 p. (Coleção ABRH de Recursos Hídricos, 4). . Água no meio urbano. Academia Brasileira de Ciências, Instituto de Estudos Avançados da USP. 1999, p. 475-507. 